\title{
Potential impact of carbonaceous aerosol on the upper troposphere and lower stratosphere (UTLS) and precipitation during Asian summer monsoon in a global model simulation
}

\author{
Suvarna Fadnavis ${ }^{1}$, Gayatry Kalita ${ }^{1}$, K. Ravi Kumar ${ }^{1,4}$, Blaž Gasparini ${ }^{2}$, and Jui-Lin Frank Li $^{3}$ \\ ${ }^{1}$ Indian Institute of Tropical Meteorology, Pune, India \\ ${ }^{2}$ Institute for Atmospheric and Climate Science, ETH Zurich, Zurich, Switzerland \\ ${ }^{3}$ Jet Propulsion Laboratory, California Institute of Technology, Pasadena, California, USA \\ ${ }^{4}$ King Abdullah University of Science and Technology, Thuwal, Saudi Arabia
}

Correspondence to: Suvarna Fadnavis (suvarna@tropmet.res.in)

Received: 3 March 2017 - Discussion started: 17 March 2017

Revised: 29 August 2017 - Accepted: 29 August 2017 - Published: 28 September 2017

\begin{abstract}
Recent satellite observations show efficient vertical transport of Asian pollutants from the surface to the upper-level anticyclone by deep monsoon convection. In this paper, we examine the transport of carbonaceous aerosols, including black carbon (BC) and organic carbon (OC), into the monsoon anticyclone using of ECHAM6-HAM, a global aerosol climate model. Further, we investigate impacts of enhanced (doubled) carbonaceous aerosol emissions on the upper troposphere and lower stratosphere (UTLS), underneath monsoon circulation and precipitation from sensitivity simulations.

The model simulation shows that boundary layer aerosols are transported into the monsoon anticyclone by the strong monsoon convection from the Bay of Bengal, southern slopes of the Himalayas and the South China Sea. Doubling of emissions of both BC and OC aerosols over Southeast Asia $\left(10^{\circ} \mathrm{S}-50^{\circ} \mathrm{N}, 65-155^{\circ} \mathrm{E}\right)$ shows that lofted aerosols produce significant warming $(0.6-1 \mathrm{~K})$ over the Tibetan Plateau (TP) near $400-200 \mathrm{hPa}$ and instability in the middle/upper troposphere. These aerosols enhance radiative heating rates $(0.02-$ $0.03 \mathrm{~K} \mathrm{day}^{-1}$ ) near the tropopause. The enhanced carbonaceous aerosols alter aerosol radiative forcing (RF) at the surface by $-4.74 \pm 1.42 \mathrm{~W} \mathrm{~m}^{-2}$, at the top of the atmosphere (TOA) by $+0.37 \pm 0.26 \mathrm{~W} \mathrm{~m}^{-2}$ and in the atmosphere by $+5.11 \pm 0.83 \mathrm{~W} \mathrm{~m}^{-2}$ over the TP and Indo-Gangetic Plain region $\left(15-35^{\circ} \mathrm{N}, 80-110^{\circ} \mathrm{E}\right)$. Atmospheric warming increases vertical velocities and thereby cloud ice in the upper troposphere. Aerosol induced anomalous warming over
\end{abstract}

the TP facilitates the relative strengthening of the monsoon Hadley circulation and increases moisture inflow by strengthening the cross-equatorial monsoon jet. This increases precipitation amounts over India $\left(1-4 \mathrm{~mm} \mathrm{day}^{-1}\right)$ and eastern China $\left(0.2-2 \mathrm{~mm} \mathrm{day}^{-1}\right)$. These results are significant at the $99 \%$ confidence level.

\section{Introduction}

Southeast Asia $\left(10^{\circ} \mathrm{S}-50^{\circ} \mathrm{N}, 65-155^{\circ} \mathrm{E}\right)$ is one of the fastest-growing regions in terms of population and economy, and it contributes significantly to the emission of global aerosol particles (Ramanathan and Crutzen, 2003; Lin et al., 2013). India and China are the two main contributors in Asia (Carmichael et al., 2009; Lin et al., 2014; Butt et al., 2016). Black carbon (BC) and organic carbon (OC) are the important aerosol species as they substantially contribute to the climate forcing (Penner et al., 1998; Chung and Seinfeld, 2002; Ramanathan and Carmichael, 2008; Hodnebrog et al., 2014) and alter the energy balance in the atmosphere and the global water cycle (Solomon et al., 2007). Recent studies show that their impacts on local meteorology and monsoon circulation are large (Ackerman et al., 2000; Ramanathan et al., 2001a, b; Lelieveld et al., 2001; Menon et al., 2002; Manoj et al., 2011). BC and OC together account for more than $60 \%$ of the aerosol optical depth (AOD) (Chin et al., 2009; Streets et al., 2009). 

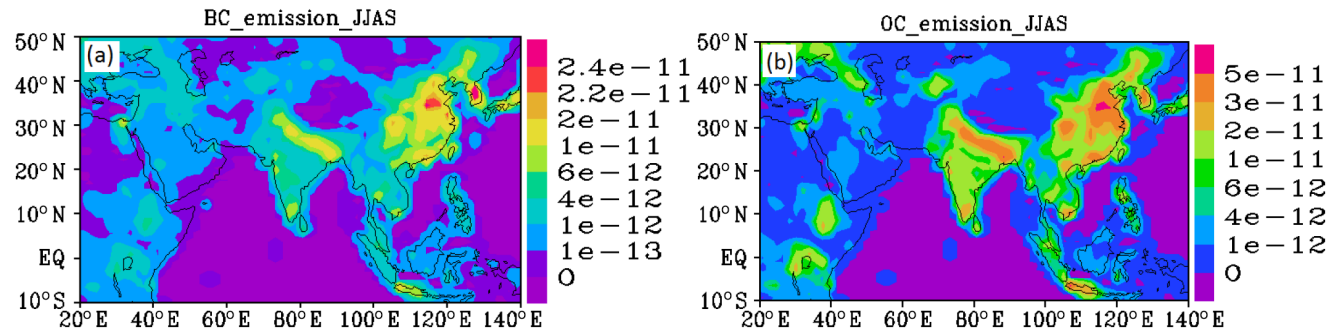

Figure 1. Distribution of emission mass flux $\left(\mathrm{kg} \mathrm{m}^{-2} \mathrm{~s}^{-1}\right)$ averaged for the monsoon season (June-September) for (a) BC and (b) OC aerosols.

There is ever-growing concern for rapidly increasing anthropogenic emissions of carbonaceous aerosols, namely BC and OC. Global emissions of BC have almost doubled during the past century (Baron et al., 2009). Developing countries in Asia, e.g., India and China, produce BC emissions at high growth rates. These countries together produced about $40 \%$ of total world BC emissions from combustion (Kopp and Mauzerall, 2010). The estimated growth of BC is $46 \%$ ( $33 \%$ in OC) over China and $41 \%$ (35\% in OC) over India during 2000 to 2010 (Lu et al., 2011). On a regional scale, their emissions are high over the densely populated Indo-Gangetic Plain in India and in eastern China (Kumar et al., 2011; Lelieveld, 2001; Gautam et al., 2011; Fadnavis et al., 2013; Zhang et al., 2015). Over the Asian region (here specifically the Indo-Gangetic Plain and northeastern China) emission of $\mathrm{OC}$ is almost twice that of $\mathrm{BC}$ (Fig. 1).

The majority of $\mathrm{BC}$ and $\mathrm{OC}$ aerosols are formed by incomplete combustion (Satheesh and Ramanathan, 2000; Carmichael et al., 2009). The important emission sources of BC aerosols are diesel vehicles, exhaust from coal-based power plants, exhaust from industries, forest fires and residential bio-fuel and fossil-fuel combustion. The OC aerosols are emitted from fossil fuel and biofuel burning and natural biogenic emissions. Biogenic carbonaceous aerosols are produced from plant debris, pollen, fungal spores, and bacteria (Jacobson et al., 2000; Bond et al., 2004) and secondary organic aerosols are produced through the oxidation of volatile organic compounds (VOCs) (Solomon et al., 2007).

Recent satellites, Cloud Aerosol Lidar and Infrared Path Finder Satellite Observation (CALIPSO) (Vernier et al., 2011; Thomason and Vernier, 2013), Stratospheric Aerosol and Gas Experiment II (SAGE) (Thomason and Vernier, 2013) and balloon sonde (Vernier et al., 2015) observations show the Asian tropopause aerosol layer (ATAL) near the tropopause persisting during the monsoon season (JuneSeptember). Satellite observations reveal transport of trace gases (CO, PAN, $\left.\mathrm{H}_{2} \mathrm{O}, \mathrm{HCN}\right)$ into the upper-level monsoon anticyclone by deep monsoon convection (Park et al., 2009; Randel et al., 2010; Kunze et al., 2010; Ploeger et al., 2011, 2012, 2013; Fadnavis et al., 2014, 2015; Govardhan et al., 2017). Moreover, both back trajectory analysis based on CALIOP observations (Vernier et al., 2015) and modeling studies (Fadnavis et al., 2013) indicate that deep monsoon convection transports boundary layer aerosols into the upper troposphere and lower stratosphere (UTLS). Measurements from the Civil Aircraft for Regular Investigation of atmosphere Based on an Instrument Container (CARIBIC) campaign show aerosols at the lower levels in the ATAL contain higher levels of carbonaceous and sulfate aerosols. The ratio of carbon to sulfur is $\sim 4.0$, with concentrations of carbon $\sim 36 \mathrm{ng} \mathrm{m}^{-3}$ and sulfur $\sim 13 \mathrm{ng} \mathrm{m}^{-3}$ in the Asian upper troposphere during August 2006, 2007 and 2008 (Vernier et al., 2015). Carbonaceous aerosols in the upper troposphere lead to atmospheric heating due to their absorptive properties, which may subsequently alter the atmospheric thermal structure and cloud amounts. Higher concentrations of carbonaceous aerosols in the ATAL may significantly alter the thermal structure of the UTLS and therefore the underneath monsoon circulation (Meehl et al., 2008; Kloster et al., 2009). The ATAL may affect the radiative forcing (RF) regionally. Vernier et al. (2015) reported that the ATAL had exerted a short-term regional forcing at the TOA of $\sim-0.1 \mathrm{~W} \mathrm{~m}^{-2}$ during the past two decades.

$\mathrm{BC}$ and $\mathrm{OC}$ aerosols absorb and scatter radiation, resulting in heating of the atmosphere, and a layer of aerosols in the UTLS may reduce solar radiation reaching the Earth's surface (Penner et al., 1998). The global mean estimated cumulative (since 1970) BC radiative effect is $+0.3 \mathrm{~W} \mathrm{~m}^{-2}$, while OC emitted from fossil fuels is estimated to be $-0.1 \mathrm{~W} \mathrm{~m}^{-2}$ (Myhre et al., 2013). The presence of BC aerosols can change the sign of forcing from negative to positive (Haywood and Shine, 1997). Studies pertaining to BC/OC RF are sparse over the Indian region. Sreekanth et al. (2007) reported BC RF at the top of the atmosphere (TOA) +2.36 and $-9.9 \mathrm{~W} \mathrm{~m}^{-2}$ at the surface at Visakhapatnam $\left(17.7^{\circ} \mathrm{N}\right.$, $83.3^{\circ} \mathrm{E}$ ) during the monsoon season 2006. Babu et al. (2002) obtained $\mathrm{BC} \mathrm{RF}+5 \mathrm{~W} \mathrm{~m}^{-2}$ at the TOA and at the surface $-23 \mathrm{~W} \mathrm{~m}^{-2}$ at Bangalore $\left(13^{\circ} \mathrm{N}, 77^{\circ} \mathrm{E}\right)$ during NovemberDecember 2001. Badarinath and Latha (2006) reported BC $\mathrm{RF}$ of $+9 \mathrm{~W} \mathrm{~m}^{-2}$ at the TOA and $-33 \mathrm{~W} \mathrm{~m}^{-2}$ at the surface at Hyderabad $\left(78^{\circ} \mathrm{E}, 17^{\circ} \mathrm{N}\right)$, India, during JanuaryMay 2005.

The Asian summer monsoon (ASM) has a major impact on agriculture, water resources, and economy and society. 
Therefore it is important to study the impact of fast-growing Asian emission of carbonaceous aerosols on monsoon precipitation. However, there are a few studies reporting the impacts of carbonaceous aerosols on precipitation over India (Meehl et al., 2008; Wang et al., 2009; Ganguly et al., 2012) and China (Guo et al., 2013, 2015). Since convective transport (during the monsoon season) inter-links tropospheric processes with the UTLS (Randel et al., 2010; Vogel et al., 2011, 2015; Fadnavis et al., 2013), it is essential to understand impacts of boundary layer emissions on the UTLS. To our knowledge, transport of carbonaceous aerosols from the boundary layer to upper troposphere and their impacts on the UTLS and connecting monsoon circulation are not explored in detail. In this study we address the question of the impact of rapidly growing Asian emissions of carbonaceous aerosols (BC and OC) on the thermal structure of the UTLS, monsoon transport processes and rainfall over India and China. We perform control and sensitivity simulations using the ECHAM6-HAM aerosol climate model. In sensitivity experiment, we have doubled anthropogenic emissions of both $\mathrm{BC}$ and $\mathrm{OC}$ over Southeast Asia $\left(10^{\circ} \mathrm{S}-50^{\circ} \mathrm{N}\right.$, $\left.65-155^{\circ} \mathrm{E}\right)$. The paper is organized as follows. In Sect. 2 model simulations and satellite observations are described. The transport processes are discussed in Sect. 3. The impacts of enhanced carbonaceous aerosol emissions on the UTLS and monsoon precipitation are described in Sect. 4, and conclusions are given in Sect. 5.

\section{Model simulations and satellite data analysis}

\subsection{Experimental setup and model simulations}

The fully coupled aerosol-climate model ECHAM6-HAM (version echam6.1.0-ham2.1-moz0.8) used in this study comprises the general circulation model ECHAM6 (Stevens et al., 2013) coupled to the aerosol sub-module Hamburg Aerosol Model (HAM) (Stier et al., 2005; Zhang et al., 2012). HAM predicts the evolution of sulfate (SU), black carbon (BC), particulate organic matter (POM), sea salt (SS), and mineral dust (DU) aerosols. The size distribution of aerosol population being described by seven lognormal modes with prescribed variance as in the M7 aerosol module (Vignati et al., 2004; Stier et al., 2005; Zhang et al., 2012). Moreover, HAM uses the two-moment cloud microphysics scheme in which the nucleation scavenging of aerosol particles by acting as cloud condensation nuclei $(\mathrm{CCN})$ or ice nuclei, freezing and evaporation of cloud droplets and melting and sublimation of ice crystals is treated explicitly (Lohmann and Ferrachat, 2010; Neubauer et al., 2014). The anthropogenic and fire emissions of $\mathrm{SO}_{2}, \mathrm{BC}$, and $\mathrm{OC}$ are based on the AEROCOM-ACCMIP-II emission inventory. The anthropogenic emissions are based on Lamarque et al. (2010). The biomass burning emissions are from GICC (1850-1950; Mieville et al., 2010), RETRO (1960-1990; Schultz et al.,
2008) and GFED v2 (1997-2008; van der Werf et al., 2006). Biogenic emissions are derived from MEGAN (Guenther et al., 1995), and fossil fuel sources are provided by the ACCMIP inventory (Lamarque et al., 2010). In the model, biogenic OC is directly inserted via emissions. Secondary organic aerosol (SOA) emissions are as described by Dentener et al. (2006). The emissions of sea salt (Guelle et al., 2001; Stier et al., 2005) and dust (Tegen et al., 2002; Cheng et al., 2008) are computed interactively.

The model simulations are performed at the spectral resolution of T63. This spectral representation is associated with a horizontal resolution of $1.875^{\circ} \times 1.875^{\circ}$ on a Gaussian grid and a vertical resolution of 47 levels spanning from the surface up to $0.01 \mathrm{hPa}$. The simulations have been carried out at a time step of $20 \mathrm{~min}$. AMIP sea surface temperature (SST) and sea ice cover (SIC) are used as lower boundary conditions. Note that our base year for aerosol and trace gas emissions is 2000. Each simulation was performed for the 30 years from January 1979 to December 2009. We analyze simulated data for 20 years (1989-2009) considering initial 10 years as spin-up time. Emissions are the same in each simulation, and meteorology varied because of different monthly sea surface temperature (SST) and sea ice (SIC) data. The interactive aerosols change the meteorology and feedback to aerosol variations. Most of the models underestimate BC and OC mass concentrations observed over Asia (Bond et al., 2013; Butt et al., 2016; Winiger et al., 2016). Bond et al. (2013) have suggested that global atmospheric absorption attributable to black carbon is too low in many models and should be increased by a factor of 3 . Butt et al. (2016) obtained better predictions when residential carbonaceous emissions were doubled. We performed a control experiment (CTRL) with baseline emissions (for the year 2000) and three sensitivity simulations for doubling of carbonaceous aerosols over the Asian region: (1) Demiss, in which emissions of both BC and OC are doubled; (2) DBConly, in which emissions of only $\mathrm{BC}$ aerosols are doubled; and (3) DOConly, in which only OC aerosols are doubled. We compare the CTRL simulation with Demiss scenario to analyze the impacts of doubled carbonaceous emissions (BC and OC together) on the UTLS and rainfall during the ASM season (June-September). We also provide the contribution of BC and OC aerosols separately from comparison of CTRL with DBConly and DOConly simulations.

\subsection{Satellite measurements}

\subsubsection{The Tropical Rainfall Measuring Mission (TRMM)}

The Tropical Rainfall Measuring Mission (TRMM) is a joint National Aeronautics and Space Administration (NASA) and Japan Aerospace Exploration (JAXA) satellite mission to monitor the tropical and subtropical precipitation and estimate its associated latent heat. TRMM was launched in 1997 
from Tanegashima space center in Japan. The rainfall measuring instruments on the TRMM satellite include an electronically scanning radar Precipitation Radar (PR) (operating at $13.6 \mathrm{GHz}$ ); the TRMM microwave imager (TMI), a nine-channel passive microwave radiometer (which records radiation at the $10.65,19.35,37.0,85.5(\mathrm{~V}$ and $\mathrm{H})$ and 21.3 (V) $\mathrm{GHz}$ ); and the Visible and Infrared Scanner (VIRS), with five operating channels (Kummerow et al., 1998). The 3B42 algorithm produces TRMM-adjusted merged infrared precipitation rate and root mean square (RMS) precipitation error estimates (Huffman et al., 2007). The algorithm combines multiple independent precipitation estimates from the TMI, Advanced Microwave Scanning Radiometer for Earth Observing Systems (AMSR-E), Special Sensor Microwave Imager (SSMI), Special Sensor Microwave Imager/Sounder (SSMIS), Advanced Microwave Sounding Unit (AMSU), Microwave Humidity Sounder (MHS), and microwaveadjusted merged geo-infrared (IR). The final 3B42 precipitation (in $\mathrm{mm} \mathrm{h}^{-1}$ ) estimates have a 3-hourly temporal resolution and a $0.25^{\circ}$ by $0.25^{\circ}$ spatial resolution. TRMM precipitation can be obtained from https://disc2.gesdisc.eosdis.nasa. gov/data/TRMM_L3/TRMM_3B42.7/. Three-hourly precipitation data are averaged to obtain daily mean. Then, seasonal mean (June-September) is computed from daily mean data. Further, seasonal mean data are averaged for 20 years (19972016) to obtain climatology of the monsoon season.

\subsubsection{CloudSat and Cloud-Aerosol Lidar Infrared Pathfinder Satellite Observations (CALIPSO)}

Cloud-Aerosol Lidar and Infrared Pathfinder Satellite Observation (CALIPSO) and CloudSat are two A-Train constellation satellites, launched together in April 2006. They provide information related to the role of cloud and aerosol in the Earth's climate system and radiative imbalance of the atmosphere. The Cloud Profiling Radar (CPR) onboard the CloudSat satellite is a $94 \mathrm{GHz}$ nadir-looking radar which measures the power backscattered by clouds as a function of distance. It provides information on cloud abundance, distribution, structure, and radiative properties (Stephens et al., 2008). The Cloud-Aerosol Lidar with Orthogonal Polarization (CALIOP) is an elastically backscattered active polarization-sensitive lidar instrument onboard CALIPSO. CALIOP transmits laser light simultaneously at 532 and $1064 \mathrm{~nm}$ at a pulse repetition rate $20.16 \mathrm{~Hz}$. The lidar receiver subsystem measures backscatter intensity at $1064 \mathrm{~nm}$ and two orthogonally polarized components of $532 \mathrm{~nm}$ backscatter signal that provide the information on the vertical distribution of aerosols and clouds, cloud particle phase, and classification of aerosol size (Winker et al., 2010; Powell et al., 2013). In this study, we use ice water content (IWC) dataset from the combined measurement of CloudSat and CALIPSO (2C-ICE_L3_V01) for the period 2007-2010. The 2C-ICE cloud product is an ice cloud retrieval derived from the combination of the CloudSat radar and CALIPSO lidar, using a variational method for retrieving profiles of the IWC in ice clouds (Deng et al., 2013). The details of the data retrieval method are explained in Li et al. (2012). IWC data have been averaged for the monsoon season and period 2007-2010 to obtained seasonal climatology.

\subsection{Comparison with in situ measurements}

We compare CTRL simulated BC concentrations with (1) aircraft measurements at Guwahati $\left(26^{\circ} 11^{\prime} \mathrm{N}, 91^{\circ} 44^{\prime} \mathrm{E}\right)$ on 30 August, 4 and 6 September 2009 from Rahul et al. (2014) and (2) balloon-borne measurements at Hyderabad $\left(17^{\circ} 48^{\prime} \mathrm{N}, 78^{\circ} 40^{\prime} \mathrm{E}\right.$ ) (Aethalometer installed on the hydrogen-inflated balloon) on 17 March 2010 from Babu et al. (2011). The model is not forced with meteorology; therefore, daily variations are not reproduced. Hence, for comparison, monthly mean simulated BC concentrations are extracted at the grid centered at Guwahati and Hyderabad. Figure $2 \mathrm{a}-\mathrm{d}$ show the comparative analysis of model simulated $\mathrm{BC}$ and in situ measurements. It can be seen that the model underestimates $\mathrm{BC}$ emissions; therefore, we additionally compare in situ measurements with Demiss simulations. The profiles of $\mathrm{BC}$ concentration obtained from the Demiss simulation show reasonable agreement with observations at Guwahati in the lower troposphere below $3 \mathrm{~km}$, while differences are large between 3 and $6 \mathrm{~km}$. Simulated BC profiles (both CTRL and Demiss) show large differences with observations at Hyderabad (Fig. 2d). These balloonborne measurements show a variation of BC between 1000 and $10000 \mathrm{ng} \mathrm{m}^{-3}$ from surface to $8.5 \mathrm{~km}$ while simulated $\mathrm{BC}$ concentration varies between 2 and $3000 \mathrm{ng} \mathrm{m}^{-3}$ for the same altitudes. The differences between in situ measurements (balloon-borne and aircraft) and model simulations may be due to number of factors such as the uncertainty in BC emissions in the model's emission inventory, uncertainty in the model's transport processes, and its coarse spatial grid $\left(1.875^{\circ} \times 1.875^{\circ}\right)$ compared to point measurement. Moreover, the meteorological conditions of each individual measurement day cannot be captured by monthly average values from the model output. The large differences at Hyderabad may be due to uncertainty in measurements due to attachment of the Aethalometer to the balloon. Although there are differences in the troposphere, Demiss simulations show reasonable agreement with measurements near the surface at Guwahati (Fig. 2a-c) and Hyderabad (Fig. 2d). A similar agreement is also observed with observations near the surface $(0-2 \mathrm{~km})$ at Kanpur $\left(80^{\circ} 20^{\prime} \mathrm{E}, 26^{\circ} 26^{\prime} \mathrm{N}\right)$ (Tripathi et al., 2007). The BC concentrations at Kanpur obtained from Demiss simulations $\sim 7.5-3 \mu \mathrm{g} \mathrm{m}^{-3}$ are comparable with observations $\sim 8-4 \mu \mathrm{g} \mathrm{m}^{-3}$.

Figure $2 \mathrm{e}$ and $\mathrm{f}$ show the vertical distribution of cloud ice obtained from CTRL simulation and climatology of the seasonal mean from combined measurement of CloudSat and CALIPSO (2C-ICE) (2007-2010), respectively, averaged for the monsoon season (June-September) and the ASM region 

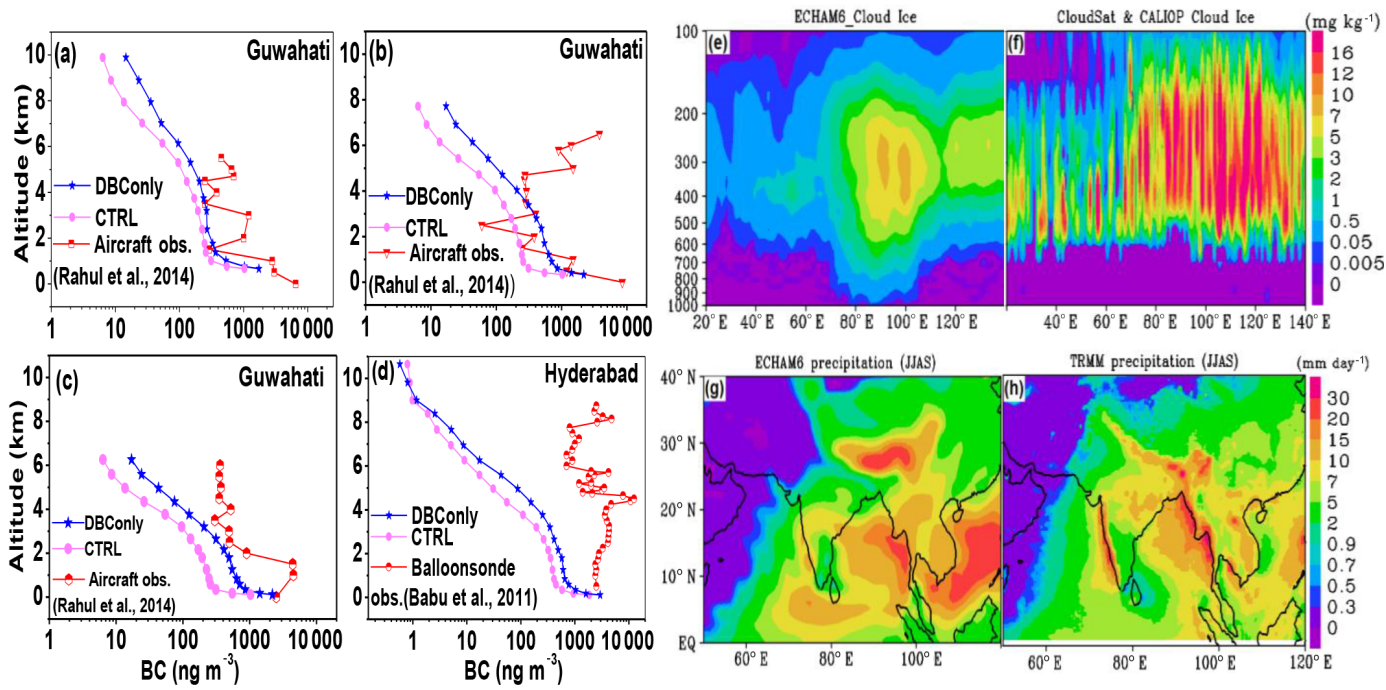

Figure 2. Vertical distribution of $\mathrm{BC}$ aerosols $\left(\mathrm{ng} \mathrm{m}^{-3}\right)$. (a) Aircraft measurements on 30 August 2009 at $\mathrm{Guwahati}\left(26^{\circ} 11^{\prime} \mathrm{N}, 91^{\circ} 44^{\prime} \mathrm{E}\right)$ (Rahul et al., 2014), CTRL and DBConly simulations for that month extracted at a grid centered at Guwahati. (b) Same as (a) but observations for 4 September 2009 and simulations for the month of September. (c) Same as (a) but for observations on 6 September 2009 and simulations for the month of September. (d) Balloon-borne measurement on 17 March 2010 at Hyderabad $\left(17^{\circ} 48^{\prime}\right.$ N, $78^{\circ} 40^{\prime}$ E) (Babu et al., 2011) and CTRL and DBConly simulations for the month of March at a grid centered at Hyderabad. (e) Seasonal mean distribution of cloud ice mass mixing ratio $\left(\mathrm{mg} \mathrm{kg}^{-1}\right)$ averaged for $20-40^{\circ} \mathrm{N}$ from CTRL simulations. (f) CloudSat and CALIPSO combined 2C-ICE L3 for the years 2007-2010. (g) Seasonal mean precipitation ( $\mathrm{mm} \mathrm{day}^{-1}$ ) obtained from CTRL simulations. (h) TRMM averaged for period 1998-2005.

$\left(60-110^{\circ} \mathrm{E}, 15-40^{\circ} \mathrm{N}\right)$. It can be seen that simulated $(3-$ $\left.10 \mathrm{mg} \mathrm{kg}^{-1}\right)$ and observed cloud ice $\left(5-17 \mathrm{mg} \mathrm{kg}^{-1}\right)$ both show high amounts in the upper troposphere $(450-200 \mathrm{hPa})$ over the ASM region. The model simulations show a maximum $\left(7-10 \mathrm{mg} \mathrm{kg}^{-1}\right)$ at $\sim 350-250 \mathrm{hPa}$ over $80-100^{\circ} \mathrm{E}$, while satellite observations $\left(12-17 \mathrm{mg} \mathrm{kg}^{-1}\right)$ show this at $\sim 450-200 \mathrm{hPa}$ over $\sim 80-120^{\circ} \mathrm{E}$. These differences may be related to uncertainties in satellite observations (Deng et al., 2010) and model biases; for example, the model does not consider large ice particles unlike the cloud ice measurement from CloudSat and CALIPSO. The total ice water mass estimates from 2C-ICE combine measurements from CALIPSO lidar depolarization, which is sensitive to small ice particles (i.e., cloud ice represented in global climate models), and CloudSat radar, which is very sensitive to larger ice particles (i.e., precipitating ice or snow). In most global climate models, including all versions of CMIP3 and most of those of CMIP5, only small particles (i.e., cloud ice) are represented prognostically. The mass of large ice particles (about twothirds of total ice) and their radiative effects, however, are not included (e.g., Li et al., 2012, 2013).

We compare simulated (CTRL) seasonal mean (JuneSeptember) precipitation with TRMM climatology (19972016). Figure $2 \mathrm{~g}$ and $\mathrm{h}$ show the distribution of precipitation as obtained from CTRL simulation and TRMM, respectively. It can be seen that general spatial pattern of precipitation simulated by the model is in good agreement with TRMM. The model could reproduce high amounts of precipitation over the Bay of Bengal, the South China Sea, and the Western
Ghats, in agreement with a number of past studies (Wang and LinHo, 2002; Hirose and Nakamura, 2005; Xie et al., 2007; Takahashi, 2016). However, the model underestimates the rainfall over northern India and the western coast of India by $\sim 2-10 \mathrm{~mm} \mathrm{day}^{-1}$ and overestimates it over the Tibetan Plateau (TP) and the South China Sea by $\sim 5-12 \mathrm{~mm} \mathrm{day}^{-1}$. This may be related to uncertainties in emissions, transport errors, and model coarse resolution.

\section{Transportation of aerosol to the UTLS}

Figure 3a depicts the vertical distribution of carbonaceous aerosols averaged over northern India $\left(75-100^{\circ} \mathrm{E}, 25-45^{\circ} \mathrm{N}\right)$ during the annual cycle as obtained from CTRL simulation. It shows elevated levels of aerosols (BC and OC together) from the surface to the tropopause during pre-monsoon (MarchMay) and monsoon seasons. It also shows a layer of carbonaceous aerosols $\left(\sim 5 \mathrm{ng} \mathrm{m}^{-3}\right)$ in the upper troposphere $\sim 170$ $100 \mathrm{hPa}$. A layer of aerosols in the upper troposphere is also observed by satellite (SAGE II, CALIPSO) and lidar measurements during the monsoon season (Vernier et al., 2011; Thomason and Vernier, 2013; Fadnavis et al., 2013; He et al., 2014). Over the TP this aerosol layer extends above the tropopause (18-19 km) (He et al., 2014).

A prominent feature in the UTLS over the ASM region during the summer season is a large anticyclone. Satellite observations show a persistent maximum in trace gases $(\mathrm{CO}$, $\mathrm{H}_{2} \mathrm{O}$, PAN, $\mathrm{HCN}, \mathrm{CH}_{4}$, etc.) (Li et al., 2005; Randel and 

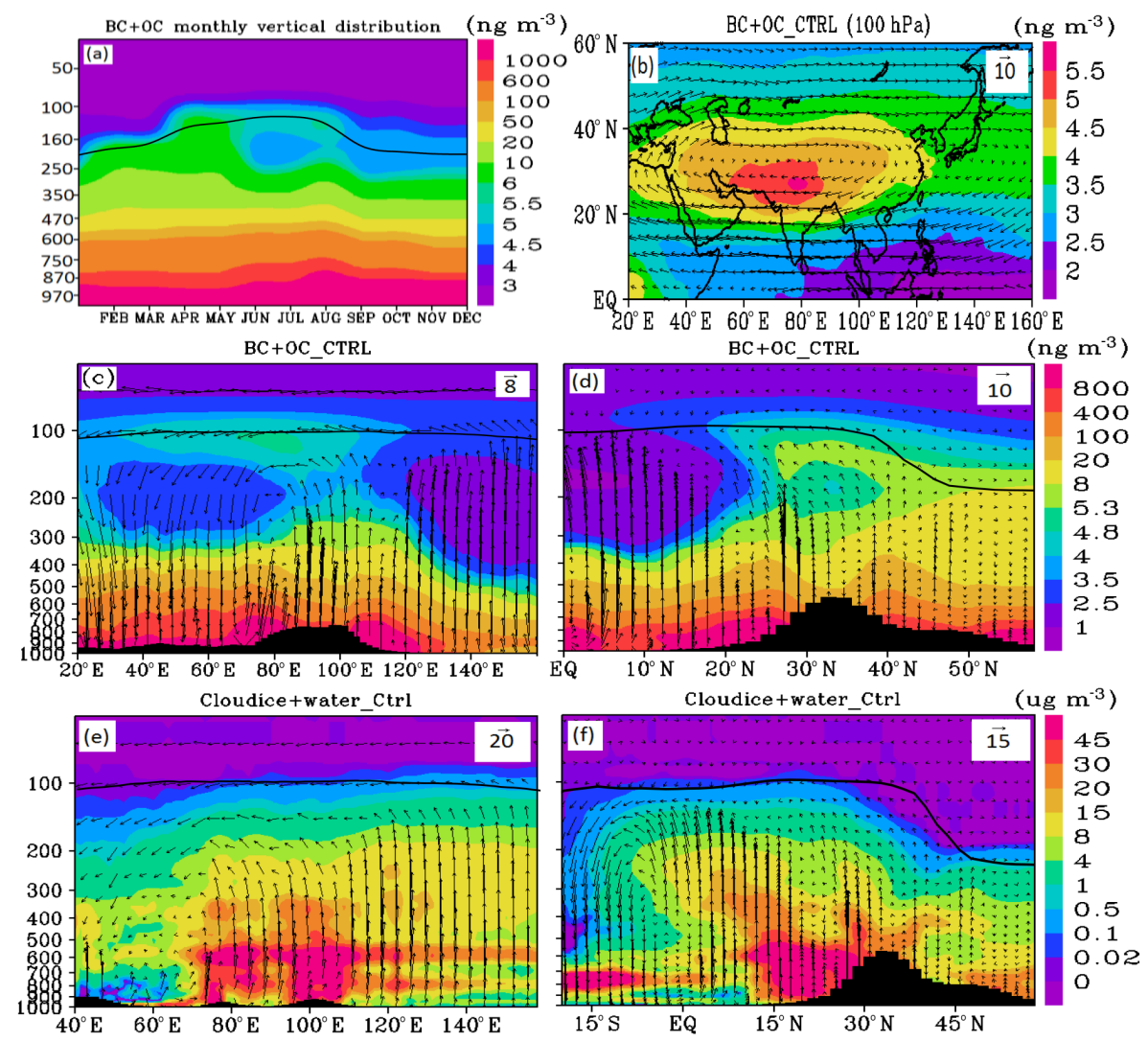

Figure 3. Distribution of BC and OC aerosols $\left(\mathrm{ng} \mathrm{m}^{-3}\right)$ together from CTRL simulations: (a) monthly variations averaged for the region 70$120^{\circ}$ E, $25-45^{\circ}$ E. Seasonal mean distribution of BC and OC aerosols $\left(\mathrm{ng} \mathrm{m}^{-3}\right)$ together from CTRL simulations: (b) at $100 \mathrm{hPa}$; (c) averaged for $15-35^{\circ} \mathrm{N}$; and (d) averaged for $80-110^{\circ}$ E. Seasonal mean distribution of cloud ice + cloud water $\left(\mu \mathrm{g} \mathrm{m}^{-3}\right.$ ) from CTRL simulations: (e) averaged for $10-25^{\circ} \mathrm{N}$ and (f) averaged for $80-110^{\circ}$ E. Black arrows indicate wind vectors. The vertical velocity field has been scaled by 1000. A black line represents the tropopause. In panels (a, c, d, e, f) the tropopause is averaged over the same region where the field parameter is averaged.

Park, 2006; Fu et al., 2006; Park et al., 2008, 2009; Randel et al., 2010; Fadnavis et al., 2013, 2014, 2015) and aerosols (Tobo et al., 2007; Vernier et al., 2011; Thomason and Vernier, 2013; Yu et al., 2015) in the ASM anticyclone. Figure $3 \mathrm{~b}$ exhibits the distribution of seasonal (June-September) mean carbonaceous aerosols (BC and $\mathrm{OC}$ together) from CTRL simulation in the anticyclone $(\sim 100 \mathrm{hPa})$. In agreement with previous studies (Tobo et al., 2007; Vernier et al., 2011), Fig. 3b also shows confinement of high carbonaceous aerosols concentration $\left(\sim 5.5 \mathrm{ng} \mathrm{m}^{-3}\right)$ within the anticyclone. The wind vector at $100 \mathrm{hPa}$ depicts the extent of the anticyclone $\left(20-120^{\circ} \mathrm{E}\right.$ and $\left.15-40^{\circ} \mathrm{N}\right)$.

Previous studies from model simulations and trajectory analysis show that rapid transport of trace gases and aerosols from Asian boundary layer into the anticyclone is closely linked with the deep ASM convection (Li et al., 2005; Randel and Park, 2006; Park et al., 2007, 2009; Xiong et al., 2009; Fadnavis et al., 2013, 2014, 2015). We plot longitude-pressure and latitude-pressure cross sections of carbonaceous aerosol from CTRL simulations to understand their transport. Figure $3 \mathrm{c}$ displays seasonal mean longitudepressure variation of carbonaceous averaged over $15-35^{\circ} \mathrm{N}$, along with wind vectors. It indicates that they are lifted up from the Bay of Bengal, Indo-Gangetic Plain $\left(70-90^{\circ} \mathrm{E}\right)$ and South China Sea $\left(110-130^{\circ} \mathrm{E}\right)$ into the anticyclone increasing the aerosol concentration to $4-6 \mathrm{ng} \mathrm{m}^{-3}$ in the UTLS (above $200 \mathrm{hPa}$ ) across $40-110^{\circ} \mathrm{E}$. Transport from southern slopes of Himalaya is evident in Fig. 3d. The vertical distribution of both BC and OC show transport from above mentioned regions into the UTLS (Fig. S1 in the Supplement). The amount of OC $\left(3-4 \mathrm{ng} \mathrm{m}^{-3}\right)$ crossing the tropopause is higher than $\mathrm{BC}\left(0.8-1 \mathrm{ng} \mathrm{m}^{-3}\right)$. Figure $3 \mathrm{e}$ and $\mathrm{f}$ show the condensed cloud water (both liquid and ice). Its maxima point out areas of frequent deep convective activity over the Bay of Bengal and the South China Sea (Fig. 3e) and the southern flanks of the Himalayas (Fig. 3f). Thus, transport of carbonaceous aerosols (seen in Fig. 3c and d) from these regions into the upper-level anticyclone may be due to deep monsoon convection. Pollution transport $\left(\mathrm{CO}, \mathrm{HCN}, \mathrm{NO}_{x}\right.$, PAN) from the Asian region to the UTLS due to monsoon 
convection is also reported by Park et al. (2007), Randel et al. (2010) and Fadnavis et al. (2014, 2015). Figure 3c and d show that a fraction of aerosols crosses the tropopause and enters into the lower stratosphere. It may be due to largescale upward motion within the anticyclone. Recently, trajectory analysis has shown that air masses within the anticyclone are transported into the lower stratosphere in the northern subtropics (Garny and Randel, 2016). We analyze the vertical profile of anomalies of carbonaceous aerosols obtained from a difference between Demiss and CTRL simulations. Longitude-pressure and latitude-pressure cross sections of the anomalies are shown in Fig. 4a and b, respectively. Enhanced anomalies are seen along the transport pathways, e.g., from the Bay of Bengal, the South China Sea and southern flanks of the Himalayas into the anticyclone. They show an enhancement of nearly $4 \mathrm{ng} \mathrm{m}^{-3}$ relative mass of aerosol near the tropopause and part of it $\left(>2 \mathrm{ng} \mathrm{m}^{-3}\right)$ enters the lower stratosphere. Comparisons of DBConly and DOConly simulations with CTRL show anomalies in BC $3-5 \mathrm{ng} \mathrm{m}^{-3}$ and OC $8-12 \mathrm{ng} \mathrm{m}^{-3}$ in the lower stratosphere (not shown).

\section{Impact of enhanced carbonaceous aerosol emissions}

\subsection{Impact on radiative forcing and heating rates}

The convectively transported carbonaceous aerosols may alter RF, heating rates, temperature, and vertical velocities in the UTLS. The carbonaceous aerosol can affect the radiative energy balance of the atmosphere directly by scattering and absorbing solar radiation and indirectly by acting as CCN (Rosenfield, 2000). Anomalies in aerosol RF estimated from Demiss, DBConly and DOConly simulation against CTRL are averaged for the monsoon season and region covering the TP and Indo-Gangetic Plain $\left(15-35^{\circ} \mathrm{N}, 80-110^{\circ} \mathrm{E}\right.$ ) (see Table 1). The seasonal mean anomaly of aerosol forcing for Demiss simulation is $+0.37 \pm 0.26 \mathrm{~W} \mathrm{~m}^{-2}$ at the TOA and $-4.74 \pm 1.42 \mathrm{~W} \mathrm{~m}^{-2}$ at the surface. The estimated aerosol forcing anomalies for DBConly (DOConly) simulation is $+0.31 \pm 0.25 \mathrm{~W} \mathrm{~m}^{-2}\left(-0.51 \pm 0.32 \mathrm{~W} \mathrm{~m}^{-2}\right)$ at the TOA and $-4.20 \pm 0.81 \mathrm{~W} \mathrm{~m}^{-2}\left(-1.96 \pm 0.95 \mathrm{~W} \mathrm{~m}^{-2}\right)$ at the surface. In comparison, AR5 assessment of global mean BC RF at the TOA is $+0.4 \mathrm{~W} \mathrm{~m}^{-2}$ (Myhre et al., 2013). The atmospheric RF is computed from the difference between forcing at TOA and surface. It represents the energy trapped in the atmosphere due to the presence of higher amounts of carbonaceous aerosols. The resultant anomaly of atmospheric aerosol RF for Demiss is $+5.11 \pm 0.83 \mathrm{~W} \mathrm{~m}^{-2}$, and $+4.52 \pm 0.38 \mathrm{~W} \mathrm{~m}^{-2}\left(+1.45 \pm 0.49 \mathrm{~W} \mathrm{~m}^{-2}\right)$ for DBConly (DOConly). Table 1 indicates that, among the carbonaceous aerosols, the major contribution in enhancing atmospheric $\mathrm{RF}$ is due to $\mathrm{BC}$ aerosols, although emission of OC is higher than $\mathrm{BC}$ aerosols over Asia. This may be due to scattering and absorbing property of OC aerosols. From Aethalometer observations, Sreekanth et al. (2007) reported BC RF at
Table 1. ECHAM6 HAM simulated total (shortwave and longwave) radiative forcing $\left(\mathrm{W} \mathrm{m}^{-2}\right)$ along with 2 standard deviation values averaged over the TP and Indo-Gangetic Plain (80-110 E, 15$35^{\circ} \mathrm{N}$ ) region.

\begin{tabular}{lrrr}
\hline Model run & TOA & Surface & Atmosphere \\
\hline Demiss-CTRL & $+0.37 \pm 0.26$ & $-4.74 \pm 1.42$ & $+5.11 \pm 0.83$ \\
DBConly-CTRL & $+0.31 \pm 0.25$ & $-4.20 \pm 0.81$ & $+4.52 \pm 0.38$ \\
DOConly-CTRL & $-0.51 \pm 0.32$ & $-1.96 \pm 0.95$ & $+1.45 \pm 0.49$ \\
\hline
\end{tabular}

the $\mathrm{TOA}+2.36$ and $-9.9 \mathrm{~W} \mathrm{~m}^{-2}$ at the surface at Visakhapatnam $\left(17^{\circ} 7^{\prime} \mathrm{N}, 83^{\circ} 3^{\prime} \mathrm{E}\right)$ during the monsoon season of the year 2006. These values are higher than anomalies of $\mathrm{BC}$ RF (DBConly-CTRL) (TOA $+1.3 \pm 0.80 \mathrm{~W} \mathrm{~m}^{-2}$ and surface $-5.0 \pm 1.31 \mathrm{~W} \mathrm{~m}^{-2}$ ) obtained at the grid centered at Visakhapatnam. These differences may be due to a comparison of point observations at Visakhapatnam with model output extracted over a grid $\left(1.875^{\circ} \times 1.875^{\circ}\right)$ centered at the same location. Also, BC aerosols are underestimated in the model (Fig. 2a-c). Pan et al. (2015) have shown that model simulations with AEROCOM-ACCMIP-II emissions underestimate AOD over south Asia (15 to $44 \%$ ) in comparison with Multi-angle Imaging SpectroRadiometer observations.

The resulting shortwave plus longwave atmospheric forcing due to doubled carbonaceous aerosols will translate to a significant atmospheric heating (Babu et al., 2002). We obtain anomalies in total heating rates (HRs) due to carbonaceous aerosols (Demiss-CTRL). Figure 4c and d show longitude-pressure (averaged for $15-35^{\circ} \mathrm{N}$ ) and latitudepressure (averaged for $80-110^{\circ} \mathrm{E}$ ) cross sections of HR anomalies during the monsoon season. Enhanced carbonaceous aerosol emissions increase HR near the surface over the Indo-Gangetic Plain, southern slopes of the Himalayas and south China. High emissions from these regions cause anomalous heating $\left(0.08 \mathrm{~K} \mathrm{day}^{-1}\right)$ in the lower troposphere (1000-600 hPa). Positive anomalies of HR can be seen along the pathway through which carbonaceous aerosols are transported into the anticyclone. The carbonaceous aerosols have increased HR by $\sim 0.02-0.03 \mathrm{~K} \mathrm{day}^{-1}$ near the tropopause in the ASM region in comparison with CTRL simulations $\left(0.006-0.01 \mathrm{~K} \mathrm{day}^{-1}\right)$. Figure S2 exhibits the latitudepressure cross section of HR anomalies for DBConly and DOConly simulations. It can be seen that, in transport pathways, anomalies of HR for DBConly simulation are higher than DOConly, although emissions of OC aerosols are higher than $\mathrm{BC}$ over Asia. This heating may be attributed to the high absorbing property of $\mathrm{BC}$ than $\mathrm{OC}$. It can be seen that HR obtained from Demiss-CTRL simulations is not just arithmetic summation of HR from DBConly-CTRL and DOConly-CTRL. This may be due to nonlinear dynamical changes due to heating by $\mathrm{BC}$ and cooling/heating effects of OC (Penner et al., 1998). Radiative heating of the tropopause region increases the vertical motion and transport into the lower stratosphere (Gettelman et al., 2004). 

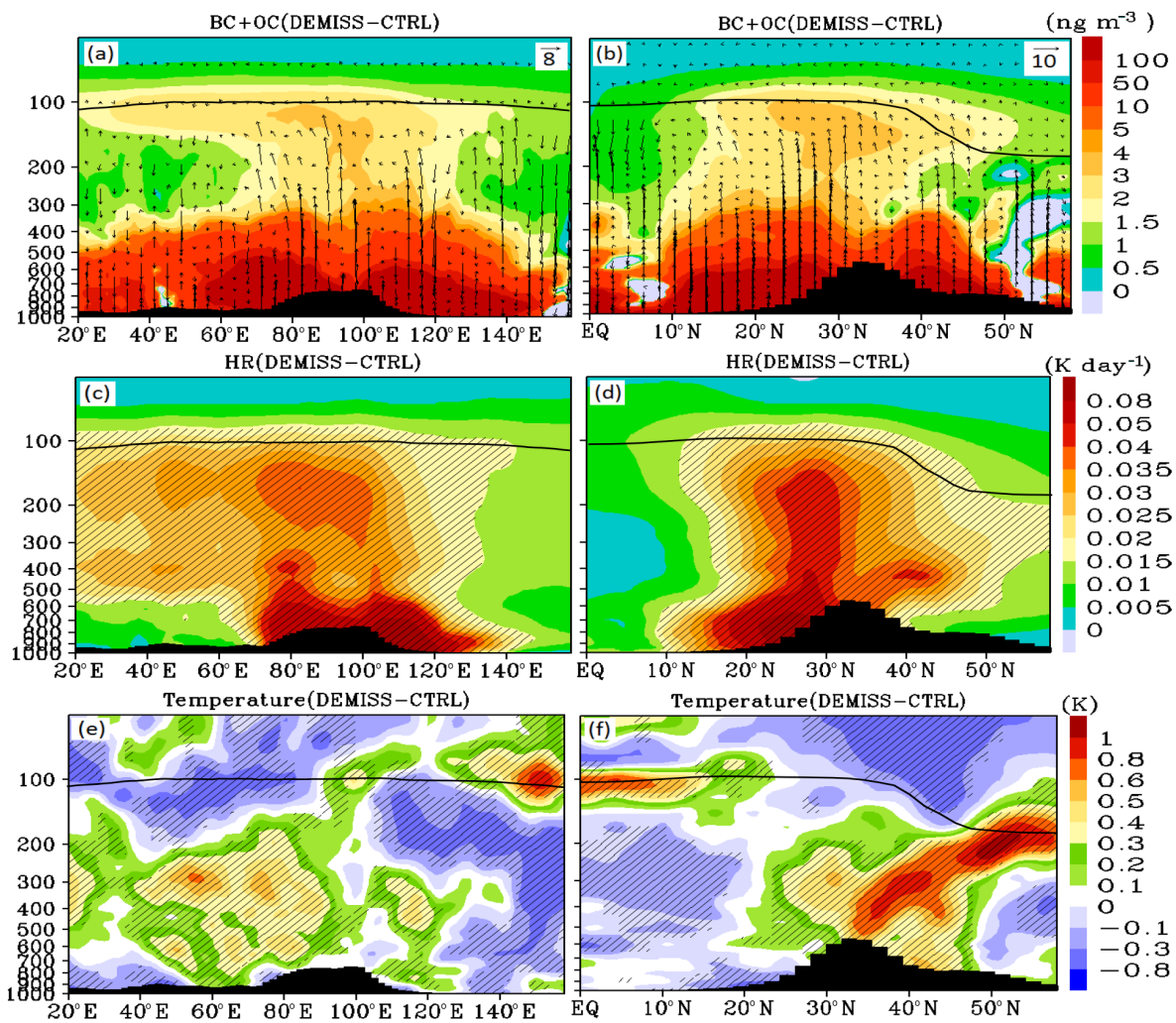

Figure 4. Distribution of seasonal mean (June-September) anomalies (Demiss-CRTL), of BC and OC aerosols (ng $\mathrm{m}^{-3}$ ) together averaged for (a) $15-35^{\circ} \mathrm{N}$ and (b) $80-110^{\circ}$ E. Black arrows indicate wind vectors (the vertical velocity field has been scaled by 1000 ). (c, d) Same as (a, b) but for heating rate anomalies $\left(\mathrm{K} \mathrm{day}^{-1}\right)$. Distribution of anomalies in temperature $(\mathrm{K})$ averaged for $(\mathbf{e}) 15-35^{\circ} \mathrm{N}$ and (f) $80-110^{\circ} \mathrm{E}$. A black line represents the tropopause. The tropopause is averaged over $15-35^{\circ} \mathrm{N}$ for panels (a, c, e) and over $80-110^{\circ} \mathrm{E}$ for panels $(\mathbf{b}, \mathbf{d}$, f). Black hatched lines in panels (c, d, e, f) indicate the $99 \%$ confidence level.

Carbonaceous aerosol anomaly enhancement $\left(>2 \mathrm{ng} \mathrm{m}^{-3}\right)$ in the lower stratosphere seen in Fig. $4 \mathrm{a}$ and b is due to an increase in vertical motion in response to enhanced aerosol HR. This indicates that aerosols induce a positive feedback in vertical transport.

\subsection{Impact on temperature, circulation and precipitation}

Further, we analyze changes in temperature induced by doubled carbonaceous aerosol emissions. Figure $4 \mathrm{e}$ and $\mathrm{f}$ show the longitude-pressure (averaged over $15-35^{\circ} \mathrm{N}$ ) and latitude-pressure (averaged over $80-110^{\circ} \mathrm{E}$ ) cross sections of temperature anomalies. These aerosols induce significant warming in the mid-troposphere $(500-300 \mathrm{hPa})$ over the ASM region (Fig. 4e) and an anomalous warm core (warming $\sim 1 \mathrm{~K})$ in the middle-upper troposphere $(\sim 400-300 \mathrm{hPa})$ over the TP (Fig. 4f). This warming may be due to heating by aerosol and water vapor together. The aerosol-induced warming may enhance water vapor transport in the middle/upper troposphere (discussed in Sect. 4.3) in response to dynamical changes. The enhanced water vapor would contribute additionally to this warming and provide positive feedback
(Fig. 8a-b). The warming over the TP in response to doubling of BC (DBConly) and OC (DOConly) aerosols individually is shown in Fig. S3. Warming due to BC aerosols is $\sim 0.3-1.2 \mathrm{~K}$ over the TP, while OC aerosols show cooling $(-0.3 \mathrm{~K})$ over the central TP and warming $(+0.6 \mathrm{~K})$ over the northern TP. This indicates that $\mathrm{BC}$ aerosols play a major role in creating a warm core over the TP. This warm core extends to midlatitudes. It is related to warming by $\mathrm{BC}$ aerosols and partially by water vapor. Figure $\mathrm{S} 4$ shows that $\mathrm{BC}$ aerosols are transported upward and northward from (latitudes 40$48^{\circ} \mathrm{N}$ ) regions of China, Mongolia, and southern Russia to the midlatitude upper troposphere, which may contribute to this warming. In addition, the negative water vapor anomalies in the same region (in the UTLS of the midlatitudes) seen in Fig. 8b imply a decreased radiative cooling, which might have partially contributed towards the warming anomaly. The warm core over the TP plays an important role in enhancing the ASM circulation (Flohn, 1957; Yanai et al., 1992; Meehl, 1994; Li and Yanai, 1996; Wu and Zhang, 1998) (discussed later in this section). Figure $4 \mathrm{e}$ shows cooling near the tropopause in the anticyclone region with a small patch of positive anomalies over the TP $\left(80-100^{\circ} \mathrm{E}\right)$. During the 

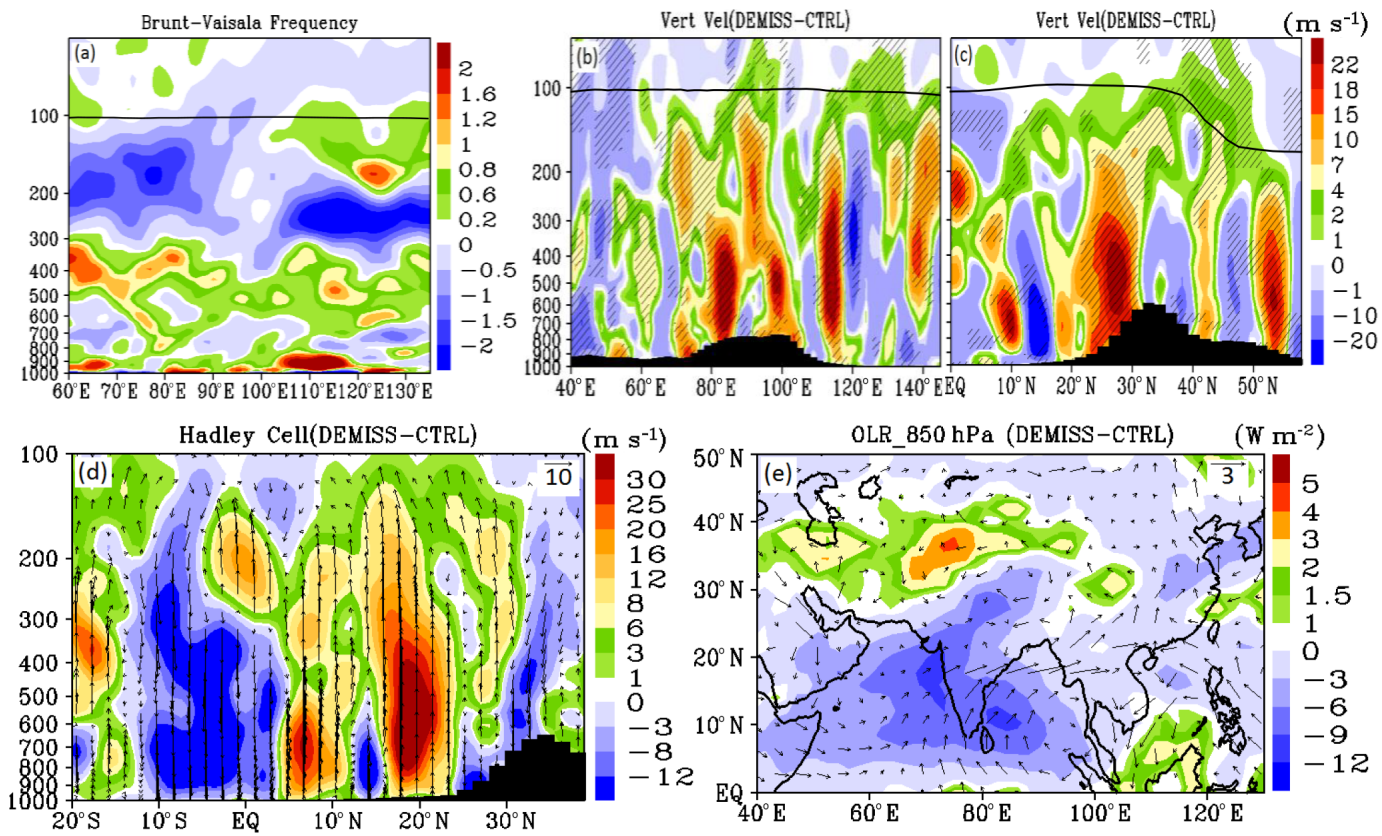

Figure 5. Vertical distribution of anomalies (Demiss-CTRL) averaged for the monsoon season. (a) Square of Brunt-Väisälä frequency $\left(\mathrm{s}^{-1} \times 10^{-5}\right)$ averaged over $25-40^{\circ} \mathrm{N}$ and (b) vertical velocities $\left(\mathrm{m} \mathrm{s}^{-1}\right)$ averaged for $15-35^{\circ} \mathrm{N}$. (c) Same as (b) but averaged for $80-$ $110^{\circ}$ E. (d) Difference in the meridional circulation averaged for $70-90^{\circ}$ E. Black arrows indicate wind vectors. (e) Distribution of outgoing longwave radiation (OLR) (shaded) $\left(\mathrm{W} \mathrm{m}^{-2}\right)$ and winds $\left(\mathrm{m} \mathrm{s}^{-1}\right)$ at $850 \mathrm{hPa}$. In panels $(\mathbf{b}-\mathbf{d})$ the vertical velocity field has been scaled by 1000 and a thick black line shows the tropopause. Black hatched lines in panels $(\mathbf{b}, \mathbf{c})$ indicate the $99 \%$ confidence level.

monsoon season, cold temperatures in the UTLS persist over the warm mid-troposphere (Randel and Park, 2006; Park et al., 2007). Our model simulations show that doubling of carbonaceous aerosol emissions amplifies the mid-tropospheric warming and cooling near the tropopause. The middle-upper tropospheric warming would enhance convective instability (Defouw, 1970). The strong negative anomalies in BruntVäisälä frequency (an indication of strong convective instability) in the middle-upper troposphere (300-200 hPa) confirm (Fig. 5a) positive feedback between warming and convective instability in the middle-upper troposphere.

During northern hemispheric summer, heating over the TP maintains a large-scale thermally driven vertical circulation (Yanai et al., 1992). The analysis of simulated vertical velocities shows that carbonaceous aerosols induce positive anomalies over the southern slope of Himalayas and IndoGangetic plains (Fig. 5b and c). Thus, carbonaceous aerosols amplify warming (Fig. 4e and f) and enhance ascending motion over these regions. Previous studies (Rajagopalan and Molnar, 2013; Vinoj et al., 2014) have reported that the warm ascending air above the TP gradually spreads southward and descends over the northern Indian Ocean. The southwesterly winds at the surface, on the other hand, complete the monsoon Hadley cell. This local circulation system releases latent heat and further maintains the Tibetan warm core. Thus, heating over the TP leads to increased Indian summer monsoon rainfall by enhancing the cross-equatorial circulation and concurrently strengthening both the Somali Jet (lowlevel jet) and the westerly winds that bring rainfall to India. Goswami et al. (1999) also reported that there is a strong correlation between monsoon Hadley circulation and precipitation. Figure 5d shows that carbonaceous aerosols strengthen the monsoon Hadley circulation, ascending over $10-20^{\circ} \mathrm{N}$ and descending over $0-10^{\circ} \mathrm{S}$. These aerosols reinforce the low-level monsoon jet $(850 \mathrm{hPa}$ ) (seen in Fig. 5e and also Fig. 5d) and outgoing longwave radiation (Fig. 5e). Figure 5e shows enhanced convection (negative anomalies in outgoing longwave radiation, OLR) is induced by the carbonaceous aerosols over the Arabian Sea, Bay of Bengal, and the majority of the Indian subcontinent, Myanmar and the region of eastern China.

The carbonaceous aerosols also indirectly affect precipitation processes by altering the $\mathrm{CCN}$ and cloud droplet number concentration (CDNC) (Rosenfeld et al., 2000). In our model simulations, doubling of carbonaceous aerosols and the related indirect effect results in enhancement of CDNC $\left(8-12 \mathrm{~m}^{-3}\right)$ and cloud water $\left(5-20 \mu \mathrm{g} \mathrm{m}^{-3}\right)$ in the region of strong convection (the Bay of Bengal, southern slopes of the Himalayas and South China Sea) in the lower troposphere (Fig. 6a-d).

Figures 4-6 suggest that enhanced emissions of carbonaceous aerosols increase the HR and amplify warm anomalies in the middle troposphere and cold anomalies near the tropopause. Aerosol-induced warming creates enhancement 

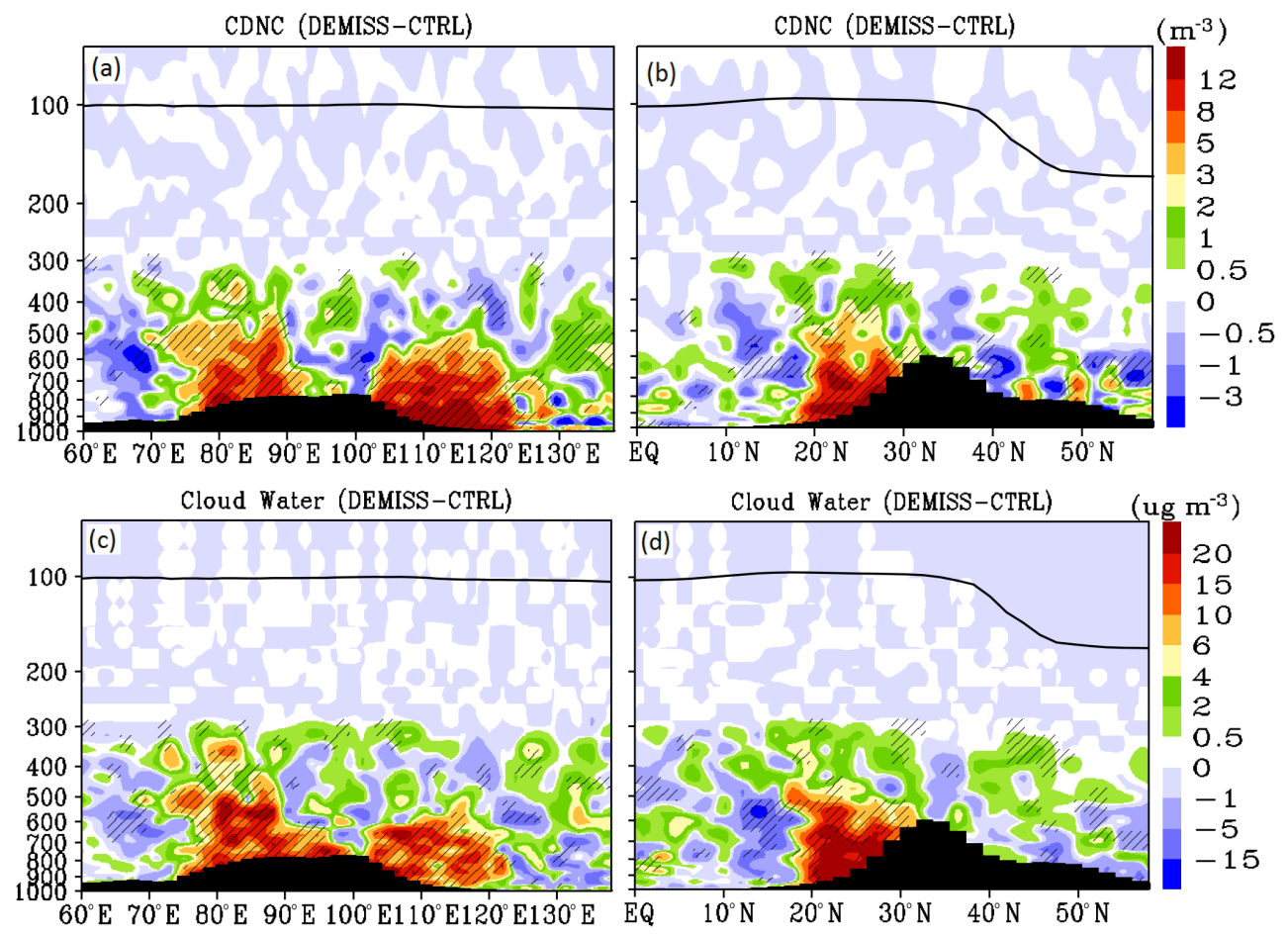

Figure 6. Distribution of anomalies (Demiss-CTRL) averaged for the monsoon season. (a) CDNC ( $\mathrm{m}^{-3}$ ) averaged for $15-35^{\circ} \mathrm{N}$. (b) Same as (a) but averaged for $80-110^{\circ}$ E. (c) Cloud water $\left(\mu \mathrm{g} \mathrm{m}^{-3}\right.$ ) averaged for $15-35^{\circ} \mathrm{N}$. (d) Same as (c) but averaged for $80-110^{\circ}$ E. In panels (a-d) a thick black line shows the tropopause and black hatched lines indicate the $99 \%$ confidence level.

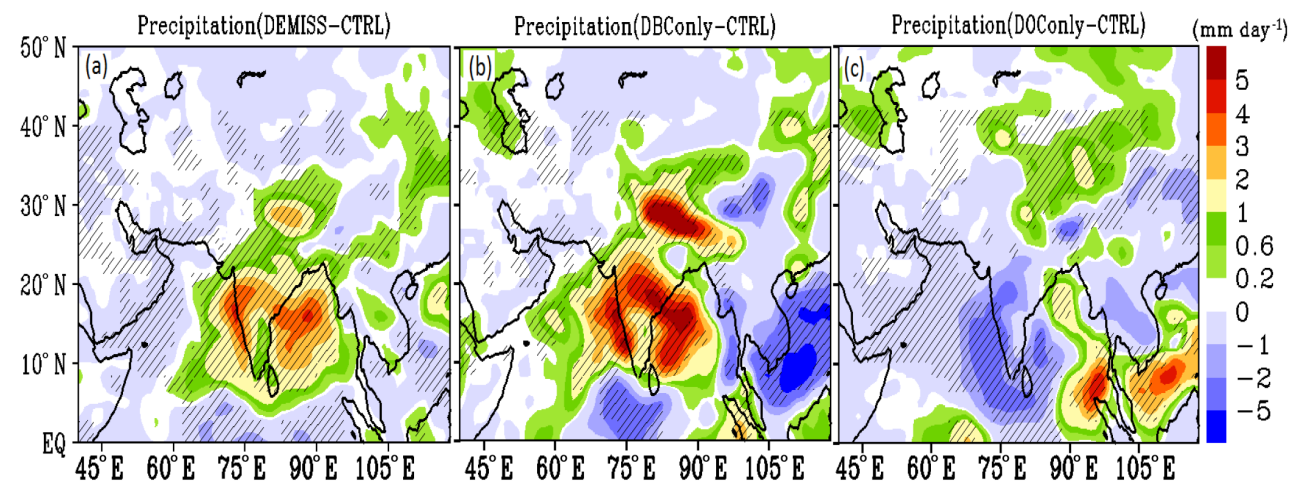

Figure 7. Distribution of anomalies in precipitation $\left(\mathrm{mmday}^{-1}\right)$ averaged for the monsoon season obtained from (a) Demiss-CTRL, (b) DBConly-CTRL and (c) DOConly-CTRL. Black hatched lines indicate the $99 \%$ confidence level.

in vertical velocities. These aerosols induce an anomalous warming over the TP which in turn strengthens the monsoon Hadley circulation, low-level monsoon jet and convection over the Indian subcontinent and eastern China. Previous studies (Meehl, 1994; Krishnamurthy and Achuthavarier, 2012) have explained the mechanism of strengthening of the monsoon Hadley circulation facilitates enhance precipitation over the Indian region. Consequently, aerosol (carbonaceous)-induced precipitation anomalies are positive over the Indian region (1-4 mm day ${ }^{-1}$ ) (Fig. 7a). Strong positive anomalies (2-4 mm day $\left.{ }^{-1}\right)$ are located over northern In- dia, the Bay of Bengal, the western coast of India and the foothills of Himalaya. There is an enhancement in precipitation over northeastern China $\left(0.2-2 \mathrm{~mm} \mathrm{day}^{-1}\right)$ and some parts of central and south China $\left(0.2-1 \mathrm{~mm} \mathrm{day}^{-1}\right)$. We show anomalies in precipitation obtained from DBConly and DOConly with respect to CTRL in Fig. 7b-c. These panels show that $\mathrm{BC}$ aerosols induce positive precipitation anomalies $\left(\sim 1-5 \mathrm{~mm} \mathrm{day}^{-1}\right)$ over the Indian region by strengthening of monsoon Hadley circulation (Fig. S5a), while OC aerosols induce negative precipitation anomalies over India $\left(-1\right.$ to $\left.-5 \mathrm{~mm} \mathrm{day}^{-1}\right)$ and northeastern China (0 to 

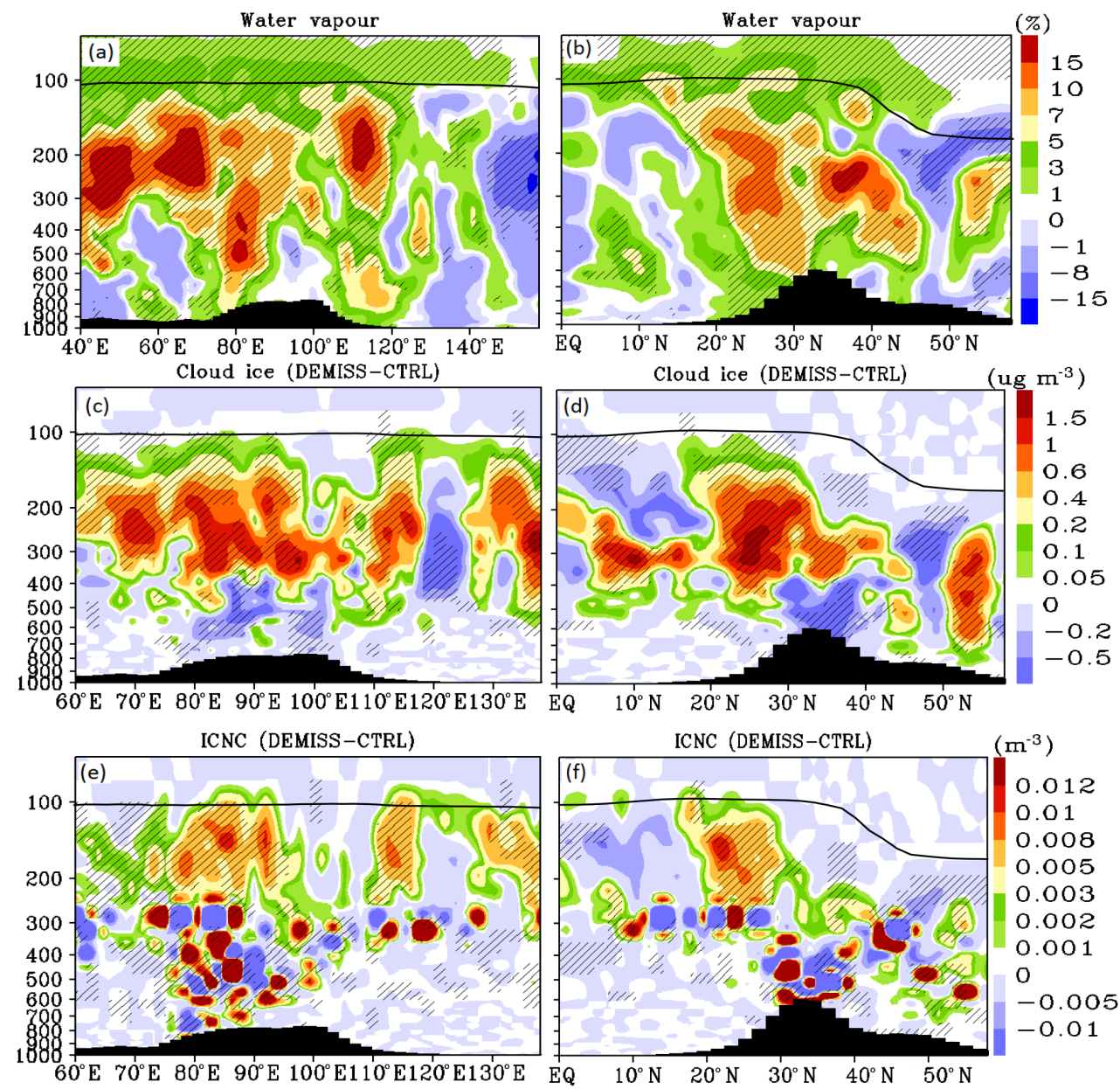

Figure 8. Distribution of anomalies (Demiss-CTRL) averaged for the monsoon season. (a) Water vapor $(\%)$ averaged over $15-35^{\circ} \mathrm{N}$. (b) Same as (a) but averaged over $80-110^{\circ}$ E. (c, d) Same as (a, b) but for cloud ice $\left(\mu \mathrm{g} \mathrm{m}^{-3}\right)$ and (e, f) for ice crystal number concentration (ICNC) $\left(\mathrm{m}^{-3}\right)$. A thick black line shows the tropopause while black hatched lines indicate the $99 \%$ confidence level. The tropopause is averaged for $15-35^{\circ} \mathrm{N}$ for panels $(\mathbf{a}, \mathbf{c}, \mathbf{e})$ and $80-110^{\circ} \mathrm{E}$ for panels $(\mathbf{b}, \mathbf{d}, \mathbf{f})$.

$-1 \mathrm{~mm} \mathrm{day}^{-1}$ ) by producing subsidence over these regions (Fig. S5b). In agreement with the present study, aerosolclimate modeling studies by Wang $(2004,2007)$ also show enhancement in precipitation over India due to black carbon direct RF. An increase in the Indian summer monsoon precipitation due to the loading of absorbing aerosol (BC and dust) has been reported in the past (Lau and Kim, 2006; Vinoj et al., 2014; Fadnavis et al., 2016). In the current study, simulations are performed with prescribed SSTs. In the model setup, interactive aerosols change the meteorology and feedback to aerosol variations. Other model studies using prescribed SSTs (Chung et al., 2002; Menon et al., 2002; Lau and Kim, 2006) also show an increase in precipitation over India due to black carbon aerosols. These model simulations did not take into account aerosol feedback with SSTs, unlike coupled atmosphere-ocean general circulation model. However, atmosphere-ocean coupled models often need multicentury simulations to take into account the slow response of SSTs (Danabasoglu and Gent, 2009). The coupled atmosphere slab ocean model by Ganguly et al. (2012) shows a mix response of precipitation distribution on the climate scale. It shows a reduction in precipitation over the western coast line of the Indian peninsula and an increase over northwestern part of Indian subcontinent. Reduction in precipitation is attributed to anthropogenic aerosols from Asia and remote locations. These differences are due to a different model setup; the present study gives an impact of doubled Asian carbonaceous aerosol emissions using an aerosolatmosphere-climate model. On the other hand, Ganguly et al. (2012) show responses of all anthropogenic and biomass burning aerosols in the context of climatic change (preindustrial and present day), also accounting for the slow response of SSTs. 


\subsection{Impact on water vapor and cloud ice}

Recently from satellite observations, Park et al. (2007) have shown that water vapor in the upper troposphere $(\sim 216 \mathrm{hPa})$ varies coherently with deep monsoon convection both temporally and spatially. Transport of high water vapor in the UTLS by the monsoon convection has been reported in the past (Gettelman et al., 2004; Dessler and Sherwood, 2004; Fu et al., 2006; Randel and Park, 2006; Braesicke et al., 2011; Ploeger et al., 2013). We analyze the difference in water vapor anomalies (Demiss-CTRL) to understand the impact of doubled Asian carbonaceous aerosol emissions on the transport of water vapor in the UTLS. Figure 8a and $b$ show an increase in water vapor in the upper troposphere and lower stratosphere 3-15\% ( 0.1-20 ppmv). Water vapor anomalies $10-15 \%(\sim 8-20 \mathrm{ppmv})$ are seen near $200 \mathrm{hPa}$ and $1-5 \%(\sim 0.1-0.8 \mathrm{ppmv})$ near the tropopause. Fadnavis et al. (2013) reported an increase in water vapor ( $\sim 0.1-10$ ppmv) in the UTLS in response to the increasing aerosols which are in agreement with the current study. In the past, Gettelman et al. (2004), Fu et al. (2006), Fadnavis et al. (2013), Garny and Randel (2016) also reported transport of water vapor above the tropopause into the lower stratosphere during the monsoon season. Enhanced aerosol emissions increase water vapor transport into the lower stratosphere by enhancing HRs, middle/upper tropospheric warming, and vertical velocities. These elevated levels of water vapor will provide positive feedback by intensifying the HRs.

In addition to thermal and dynamical impact, aerosols in the UTLS also largely influence the formation and microphysical properties of cirrus clouds. Cirrus clouds have a great impact on radiation and intensity of the large-scale tropical circulation (Randall et al., 1989; Ramaswamy and Ramanathan, 1989; Liu et al., 2003). Figure 8c-f show longitude-pressure and latitude-pressure cross sections of anomalies of cloud ice and ice crystal number concentration (ICNC). These figures show enhancement of anomalies of cloud ice (by 0.4-2 $\mathrm{g} \mathrm{m}^{-3}$ ) and ICNC (by 0.001-0.01 $\mathrm{m}^{-3}$ ) occurrence in the upper troposphere $(350-100 \mathrm{hPa})$. Maximum increase (cloud ice by $2 \mu \mathrm{g} \mathrm{m}^{-3}$, ICNC by $0.01 \mathrm{~m}^{-3}$ ), is seen in the $80-90^{\circ} \mathrm{E}, 20-30^{\circ} \mathrm{N}$, where stronger upwelling motion prevails (Fig. 8e and f). A fraction of the positive anomalies of ICNC is seen near the tropopause indicating entrainment into the lower stratosphere. Positive anomalies in cloud ice and ICNC (in the upper troposphere) are due to enhancement in ASM deep convection (increase in heating rates, middle/upper tropospheric temperature, vertical velocity, and monsoon Hadley circulation) induced by the doubling of carbonaceous aerosol emissions.

\section{Summary and conclusions}

In this paper, we investigated impacts of enhanced Asian $\left(65-155^{\circ} \mathrm{E}, 10^{\circ} \mathrm{S}-50^{\circ} \mathrm{N}\right)$ carbonaceous aerosols on the
UTLS, monsoon circulation and precipitation over India and China using a state-of-the-art aerosol-climate model. We performed sensitivity experiments for doubling of carbonaceous aerosol emission over the Asian region.

To validate the model simulations, we compare (1) a simulated BC vertical profile with observations from aircraft measurements at Guwahati $\left(26^{\circ} 11^{\prime} \mathrm{N}, 91^{\circ} 44^{\prime} \mathrm{E}\right)$, India, during August-September 2009 and an Aethalometer launched on a balloon sonde at Hyderabad $\left(78^{\circ} \mathrm{E}, 17^{\circ} \mathrm{N}\right)$ on 17 March 2010 (pre-monsoon season), (2) the seasonal mean of simulated cloud ice content with climatology of combined measurements from CloudSat and CALIPSO (2007-2010), and (3) simulated precipitation with climatology of TRMM observations (1997-2016). The aircraft measurements show reasonable agreement with $\mathrm{BC}$ concentrations obtained from doubling of carbonaceous aerosol simulation (Demiss) in the lower troposphere. In the troposphere, the difference between aircraft measurements and simulated $\mathrm{BC}$ varies with altitude. Balloon sonde measurements at Hyderabad show large differences to Demiss simulations in the troposphere. The spatial patterns of the simulated season mean (JuneSeptember) precipitation are comparable with climatology of TRMM precipitation (1997-2016) and cloud ice with combined measurements from CloudSat and CALIOP (20072010), respectively. Simulated cloud ice is underestimated by $2-7 \mathrm{mg} \mathrm{kg}^{-1}$ in the UTLS $\left(60-120^{\circ} \mathrm{E}, 15-40^{\circ} \mathrm{N}\right)$ during the summer monsoon season.

Our model simulations show that monsoon convection over the Bay of Bengal, the South China Sea and southern flanks of the Himalayas transport Asian carbonaceous aerosol into the UTLS. A persistent maximum of carbonaceous aerosols is seen within the anticyclone during the ASM season, and a fraction of these aerosols enter the lower stratosphere. Doubling emissions of carbonaceous aerosol over the Asian region leads to their enhancement (by $4-6 \mathrm{ng} \mathrm{m}^{-3}$ ) in the UTLS. They alter aerosol RF at the surface by $-4.74 \pm 1.42 \mathrm{~W} \mathrm{~m}^{-2}$, at the TOA by $+0.37 \pm 0.26 \mathrm{~W} \mathrm{~m}^{-2}$ and in the atmosphere by $+5.11 \pm 0.32 \mathrm{~W} \mathrm{~m}^{-2}$ over the TP and Indo-Gangetic Plain. Positive anomalies of heating rates are seen along the pathway through which aerosols are transported into the anticyclone. These carbonaceous aerosols increase heating rates in the anticyclone $(\sim 100 \mathrm{hPa})$ by $0.02-$ $0.03 \mathrm{~K} \mathrm{day}^{-1}$. They induce significant warming (temperature increases by $1 \mathrm{~K}$ ) in the middle/upper troposphere over the ASM region. An anomalous warming within the atmosphere enhances vertical velocities and thereby cloud ice $\left(2 \mathrm{mg} \mathrm{m}^{-3}\right)$, ICNC $\left(0.01 \mathrm{~m}^{-3}\right)$. A significant increase in water vapor transport in the upper troposphere 10-15\% $(0.5-$ $10 \mathrm{ppmv})$ and $1-5 \%(0.1-0.5 \mathrm{ppmv})$ near the tropopause is apparently related to the middle/upper tropospheric warming. Doubling of carbonaceous aerosol emissions enhances warming over the TP $(\sim 1 \mathrm{~K})$ and cold anomalies near the tropopause. The warming over the TP may be partially due to heating by water vapor creating a positive feedback. The enhanced carbonaceous aerosols strengthen the mon- 
soon Hadley circulation by intensifying warming over the TP. They strengthen the low-level monsoon jet and convection and induce precipitation enhancement over India (1$\left.4 \mathrm{~mm} \mathrm{day}^{-1}\right)$ and eastern China $\left(0.2-2 \mathrm{~mm}\right.$ day $\left.^{-1}\right)$. In agreement with the present study, aerosol-climate modeling studies by Wang $(2004,2007)$ also show enhancement in Indian summer monsoon precipitation due to black carbon direct RF.

The experiments with doubling of BC only (DBConly) and OC only (DOConly) aerosols indicate that the HRs due to BC is higher that of OC aerosols along the transport path ways (the Bay of Bengal and southern slope of the Himalayas). $\mathrm{BC}$ aerosol induces anomalous warming over the TP and enhances positive precipitation anomalies $\left(\sim 1-5 \mathrm{~mm} \mathrm{day}^{-1}\right)$ over the Indian region by strengthening of monsoon Hadley circulation. However, OC aerosol produces cooling over the central TP and generates negative precipitation anomalies over India $\left(-1\right.$ to $\left.-5 \mathrm{~mm} \mathrm{day}^{-1}\right)$ and northeastern China $(0$ to $-1 \mathrm{mmday}^{-1}$ ) by producing subsidence over these regions.

In the current study, simulations are performed with enhanced Asian carbonaceous aerosols and prescribed SSTs where interactive aerosols change the meteorology and feedback to aerosol variations. Other modeling studies using prescribed SSTs and an increase in global BC emissions also show an increase in precipitation over India (Chung et al., 2002; Menon et al., 2002; Lau and Kim, 2006). Observational evidence also shows that heavy loading of absorbing aerosols (BC and dust) over the Indian subcontinent facilitates the enhancement of monsoon rainfall over India (Lau and Kim, 2006; Vinoj et al., 2014).

We note that a realistic future emission scenario also includes the increasing emissions of sulfate aerosols and the response of climate and circulation to increasing $\mathrm{CO}_{2}$ concentrations, which might have an effect on the presented results and lead to different dynamical and climatic responses. Moreover, in future, we propose to re-evaluate the studies by using the regional model with a better resolution of the complex orography over, for example, the Himalayas/TP. Notwithstanding this, the work provides valuable insight into the influence of growing Asian carbonaceous aerosol emissions on the UTLS, connecting monsoon processes and precipitation in the Asian summer monsoon region.

Data availability. We have provided reference for the satellite, aircraft and balloonsonde data used in this paper in Sect. 2.3. (1) TRMM data are obtained from: https://disc2.gesdisc.eosdis. nasa.gov/data/TRMM_L3/TRMM_3B42.7/, (2) AEROCOM emissions are obtained from: http://aerocom.met.no/emissions.html, (3) Aircraft measurements for August-September 2009 at Guwahati $\left(26^{\circ} 110 \mathrm{~N}, 91^{\circ} 440 \mathrm{E}\right)$ are adopted from Rahul et al. (2014). (4) Balloon-borne measurements on March 2010 at Hyderabad $\left(17^{\circ} 480 \mathrm{~N}, 78^{\circ} 400 \mathrm{E}\right)$ are adopted from Babu et al. (2011). (5) CALIPSO and CloudSat measurements are obtaioned from: http://www.cloudsat.cira.colostate.edu/data-products/. These satellite data sets are freely available.

\section{The Supplement related to this article is available online at https://doi.org/10.5194/acp-17-11637-2017- supplement.}

Competing interests. The authors declare that they have no conflict of interest.

Acknowledgements. The authors acknowledges with gratitude the High Power Computing Centre (HPC) in IITM, Pune, India, for providing computer resources. The authors are thankful to the anonymous reviewers and co-editor for valuable suggestions.

Edited by: Rolf Müller

Reviewed by: two anonymous referees

\section{References}

Ackerman, A. S., Toon, O. B., Stevens, D. E., Heymsfield, A. J., Ramanathan, V., and Welton, E. J.: Reduction of tropical cloudiness by soot, Science, 288, 1042-1047, https://doi.org/10.1126/science.288.5468.1042, 2000.

Babu, S. S., Satheesh, S. K., and Moorthy, K. K.: Aerosol radiative forcing due to enhanced black carbon at an urban site in India, Geophys. Res. Lett., 29, 1880, https://doi.org/10.1029/2002GL015826, 2002.

Babu, S. S., Moorthy, K. K., Manchanda, R. K., Sinha, P. R., Satheesh, S. K., Vajja, D. P., Srinivasan, S., and Kumar, V. H. A.: Free tropospheric black carbon aerosol measurements using high altitude balloon: Do BC layers build "their own homes" up in the atmosphere?, Geophys. Res. Lett., 38, L08803, https://doi.org/10.1029/2011GL046654, 2011.

Badarinath, K. V. S. and Latha, M. K.: Direct radiative forcing from black carbon aerosols over urban environment, Adv. Space Res., 37, 2183-2188, https://doi.org/10.1016/j.asr.2005.10.034, 2006.

Baron, R. E., Montgomery, W. D., and Tuladhar, S. D.: An Analysis of Black Carbon Mitigation as a Response to Climate Change, Copenhagen Consensus Center, http://www.copenhagenconsensus.com/sites/default/files/ ap_black_carbon_baron_montgomery_tuladhar_v.4.0.pdf, 31 pp., 2009.

Bond, T. C., Streets, D. G., Yarber, K. F., Nelson, S. M., Woo, J.-H., and Klimont, Z.: A technology-based global inventory of black and organic carbon emissions from combustion, J. Geophys. Res., 109, D14203, https://doi.org/10.1029/2003JD003697, 2004.

Bond, T. C., Doherty, S. J., Fahey, D. W., Forster, P. M., Berntsen, T., DeAngelo, B. J., Flanner, M. G., Ghan, S., Kärcher, B., Koch, D., Kinne, S., Kondo, Y., Quinn, P. K., Sarofim, M. C., Schultz, M. G., Schulz, M., Venkataraman, C., Zhang, H., Zhang, S., Bellouin, N., Guttikunda, S. K., Hopke, P. K., Jacobson, M. Z., Kaiser, J. W., Klimont, Z., Lohmann, U., Schwarz, J. P., 
Shindell, D., Storelvmo, T., Warren, S. G., and Zender, C. S.: Bounding the role of black carbon in the climate system: A scientific assessment, J. Geophys. Res.-Atmos., 118, 5380-5552, https://doi.org/10.1002/jgrd.50171, 2013.

Braesicke, P., Smith, O. J., Telford, P., and Pyle, J. A.: Ozone concentration changes in the Asian summer monsoon anticyclone and lower stratospheric water vapour: An idealised model study, Geophys. Res. Lett., 38, L03810, https://doi.org/10.1029/2010GL046228, 2011.

Butt, E. W., Rap, A., Schmidt, A., Scott, C. E., Pringle, K. J., Reddington, C. L., Richards, N. A. D., Woodhouse, M. T., RamirezVillegas, J., Yang, H., Vakkari, V., Stone, E. A., Rupakheti, M., S. Praveen, P., G. van Zyl, P. P. Beukes, J., Josipovic, M., Mitchell, E. J. S., Sallu, S. M., Forster, P. M., and Spracklen, D. V.: The impact of residential combustion emissions on atmospheric aerosol, human health, and climate, Atmos. Chem. Phys., 16, 873-905, https://doi.org/10.5194/acp-16-873-2016, 2016.

Carmichael, G. H., Adhikary, B., Kulkarni, S., D’Allura, A., Tang, Y., Streets, D., Zhang, Q., Bond, T. I. C., Ramanathan, V., Jamroensan, A., and Marrapu, P.: Asian Aerosols: Current and Year 2030 Distributions and Implications to Human Health and Regional Climate Change, Environ. Sci. Technol., 43, 5811-5817, https://doi.org/10.1021/es8036803, 2009.

Cheng, T., Peng, Y., Feichter, J., and Tegen, I.: An improvement on the dust emission scheme in the global aerosol-climate model ECHAM5-HAM, Atmos. Chem. Phys., 8, 1105-1117, https://doi.org/10.5194/acp-8-1105-2008, 2008.

Chin, M., Diehl, T., Dubovik, O., Eck, T. F., Holben, B. N., Sinyuk, A., and Streets, D. G.: Light absorption by pollution, dust, and biomass burning aerosols: a global model study and evaluation with AERONET measurements, Ann. Geophys., 27, 3439-3464, https://doi.org/10.5194/angeo-27-3439-2009, 2009.

Chung, S. H. and Seinfeld, J. H.: Global distribution and climate forcing of carbonaceous aerosols, J. Geophys. Res., 107, 4407, https://doi.org/10.1029/2001JD001397, 2002.

Danabasoglu, G. and Gent, P.: Equilibrium climate sensitivity: Isit accurate to use a slab ocean model?, J. Climate, 22, 2494-2499, https://doi.org/10.1175/2008JCLI2596.1, 2009.

Defouw, R. J.: Thermal-Convective Instability, Astrophys. J., 160, 659-669, 1970.

Deng, M., Mace, G. G., Wang, Z., and Okamoto, H.: Tropical Composition, Cloud and Climate Coupling Experiment validation for cirrus cloud profiling retrieval using CloudSat radar and CALIPSO lidar, J. Geophys. Res., 115, D00J15, https://doi.org/10.1029/2009JD013104, 2010.

Deng, M., Mace, G. G., Wang, Z., and Lawsan, R. P.: Evaluation of Several A-Train Ice Cloud Retrieval Products with In Situ Measurements Collected during the SPARTICUS Campaign, J. Appl. Meteorol. Clim., 52, 1014-1030, https://doi.org/10.1175/JAMCD-12-054.1, 2013.

Dentener, F., Kinne, S., Bond, T., Boucher, O., Cofala, J., Generoso, S., Ginoux, P., Gong, S., Hoelzemann, J. J., Ito, A., Marelli, L., Penner, J. E., Putaud, J.-P., Textor, C., Schulz, M., van der Werf, G. R., and Wilson, J.: Emissions of primary aerosol and precursor gases in the years 2000 and 1750 prescribed data-sets for AeroCom, Atmos. Chem. Phys., 6, 43214344, https://doi.org/10.5194/acp-6-4321-2006, 2006.
Dessler, A. E. and Sherwood, S. C.: Effect of convection on the summertime extratropical lower stratosphere, J. Geophys. Res., 109, D23301, https://doi.org/10.1029/2004JD005209, 2004.

Fadnavis, S., Semeniuk, K., Pozzoli, L., Schultz, M. G., Ghude, S. D., Das, S., and Kakatkar, R.: Transport of aerosols into the UTLS and their impact on the Asian monsoon region as seen in a global model simulation, Atmos. Chem. Phys., 13, 8771-8786, https://doi.org/10.5194/acp-13-8771-2013, 2013.

Fadnavis, S., Schultz, M. G., Semeniuk, K., Mahajan, A. S., Pozzoli, L., Sonbawne, S., Ghude, S. D., Kiefer, M., and Eckert, E.: Trends in peroxyacetyl nitrate (PAN) in the upper troposphere and lower stratosphere over southern Asia during the summer monsoon season: regional impacts, Atmos. Chem. Phys., 14, 12725-12743, https://doi.org/10.5194/acp-14-127252014, 2014.

Fadnavis, S., Semeniuk, K., Schultz, M. G., Kiefer, M., Mahajan, A., Pozzoli, L., and Sonbawane, S.: Transport pathways of peroxyacetyl nitrate in the upper troposphere and lower stratosphere from different monsoon systems during the summer monsoon season, Atmos. Chem. Phys., 15, 11477-11499, https://doi.org/10.5194/acp-15-11477-2015, 2015.

Fadnavis, S., Chaitri, R., Sabin, T. P., Ayantika, D. C., and Ashok, K.: Potential modulations of pre-monsoon aerosols during El Niño: impact on Indian summer monsoon, Clim. Dynam., 49, 2279-2290, https://doi.org/10.1007/s00382-016-3451-6, 2016.

Flohn, H.: Large-scale aspects of the summer monsoon in South and East Asia, J. Meteorol. Soc. Jpn., 75, 180-186, available at: https://www2.meteo.uni-bonn.de/bibliothek/Flohn_ Publikationen/K81-K140_1952-1959/K127.pdf, 1957.

Fu, R., Hu, Y., Wright, J. S., Jiang, J. H., Dickinson, R. E., Chen, M., Filipiak, M., Read, W. G., Waters, J. W., and $\mathrm{Wu}$, D. L.: Short circuit of water vapour and polluted air to the global stratosphere by convective transport over the Tibetan Plateau, P. Natl. Acad. Sci. USA, 103, 5664-5669, https://doi.org/10.1073/pnas.0601584103, 2006.

Ganguly, D., Rasch, P. J., Wang, H., and Yoon, J.-H.: Climate response of the South Asian monsoon system to anthropogenic aerosols, J. Geophys. Res., 117, D13209, https://doi.org/10.1029/2012JD017508, 2012.

Garny, H. and Randel, W. J.: Transport pathways from the Asian monsoon anticyclone to the stratosphere, Atmos. Chem. Phys., 16, 2703-2718, https://doi.org/10.5194/acp-16-27032016, 2016.

Gautam, R., Hsu, N. C., Tsay, S. C., Lau, K. M., Holben, B., Bell, S., Smirnov, A., Li, C., Hansell, R., Ji, Q., Payra, S., Aryal, D., Kayastha, R., and Kim, K. M.: Accumulation of aerosols over the Indo-Gangetic plains and southern slopes of the Himalayas: distribution, properties and radiative effects during the 2009 pre-monsoon season, Atmos. Chem. Phys., 11, 1284112863, https://doi.org/10.5194/acp-11-12841-2011, 2011.

Gettelman, A., Forster, P., Fujiwara, M., Fu, Q., Vomel, H., Gohar, L. K., Johanson, C., and Ammerman, M.: Radiation balance of the tropical tropopause layer, J. Geophys. Res., 109, D07103, https://doi.org/10.1029/2003JD004190, 2004.

Goswami, B. N., Krishnamurthy, V., and Annamalai, H.: A broad scale circulation index for the interannual variability of the Indian summer monsoon, Q. J. Roy. Meteor. Soc., 125, 611-633, https://doi.org/10.1002/qj.49712555412, 1999. 
Govardhan, G., Satheesh, S. K., Nanjundiah, R., Moorthy, K. K., and Babu, S. S.: Possible climatic implications of high-altitude black carbon emissions, Atmos. Chem. Phys., 17, 9623-9644, https://doi.org/10.5194/acp-17-9623-2017, 2017.

Guelle, W., Schulz, M., Balkanski, Y., and Dentener, F.: Influence of the source formulation on modeling the atmospheric global distribution of sea salt aerosol, J. Geophys. Res., 106, 2750927524, https://doi.org/10.1029/2001JD900249,2001.

Guenther, A., Hewitt, C. N., Erickson, D., Fall, R., Geron, C., Graedel, T., Harley, P., Klinger, L., Lerdau, M., Mckay, W. A., Pierce, T., Scholes, B., Steinbrecher, R., Tallamraju, R., Taylor, J., and Zimmerman, P. A.: Global-Model of Natural Volatile Organic-Compound Emissions, J. Geophys. Res.-Atmos., 100, 8873-8892, https://doi.org/10.1029/94JD02950, 1995.

Guo, L., Highwood, E. J., Shaffrey, L. C., and Turner, A. G.: The effect of regional changes in anthropogenic aerosols on rainfall of the East Asian Summer Monsoon, Atmos. Chem. Phys., 13, 1521-1534, https://doi.org/10.5194/acp-13-1521-2013, 2013.

Guo, L., Turner, A. G., and Highwood, E. J.: Impacts of 20th century aerosol emissions on the South Asian monsoon in the CMIP5 models, Atmos. Chem. Phys., 15, 6367-6378, https://doi.org/10.5194/acp-15-6367-2015, 2015.

Haywood, J. M. and Shine, K. P.: Multi-spectral calculations of the radiative forcing of tropospheric sulphate and soot aerosols using a column model, Q. J. Roy. Meteor. Soc., 123, 1907-1930, https://doi.org/10.1002/qj.49712354307, 1997.

He, Q. S., Li, C. C., Ma, J. Z., Wang, H. Q., Yan, X. L., Lu, J., Liang, Z. R., and Qi, G. M.: Lidar-observed enhancement of aerosols in the upper troposphere and lower stratosphere over the Tibetan Plateau induced by the Nabro volcano eruption, Atmos. Chem. Phys., 14, 11687-11696, https://doi.org/10.5194/acp-14-116872014, 2014.

Hirose, M. and Nakamura, K.: Spatial and diurnal variation of precipitation systems over Asia observed by the TRMM Precipitation Radar, J. Geophys. Res., 110, D05106, https://doi.org/10.1029/2004JD004815, 2005.

Hodnebrog, O., Myhre, G., and Samset, B. H.: How shorter black carbon lifetime alters its climate effect, Nat. Commun., 5, 5065, https://doi.org/10.1038/ncomms6065, 2014.

Huffman, G. J., Adler, R. F., Bolvin, D. T., Gu, G., Nelkin, E. J., Bowman, K. P., Hong, Y., Stocker, E. F., and Wolff, D. B.: The TRMM Multi-satellite Precipitation Analysis: Quasi-Global, Multi-Year, Combined-Sensor Precipitation Estimates at Fine Scale, J. Hydrometeorol., 8, 38-55, https://doi.org/10.1175/jhm560.1, 2007.

Jacobson, M. C., Hansson, H.-C., Noone, K. J., and Charlson, R. J.: Organic atmospheric aerosols: Review and state of the science, Rev. Geophys., 38, 267-294, https://doi.org/10.1029/1998RG000045, 2000.

Kloster, S., Dentener, F., Feichter, J., Raes, F., Lohmann, U., Roeckner, E., and Burns, I. F.: A GCM study of future climate response to aerosol pollution reductions, Clim. Dynam., 34, 1177-1194, https://doi.org/10.1007/s00382-009-0573-0, 2009.

Kopp, R. E. and Mauzeralla D. L.: Assessing the climatic benefits of black carbon mitigation, P. Natl. Acad. Sci. USA, 107, 1170311708, https://doi.org/10.1073/pnas.0909605107, 2010.

Krishnamurthy, V. and Achuthavarier, D.: Intraseasonal oscillations of the monsoon circulation over South Asia, Clim. Dynam., 38, 2335-2353, https://doi.org/10.1007/s00382-011-1153-7, 2012.
Kumar, R., Naja, M., Satheesh, S. K., Ojha, N., Joshi, H., Sarangi, T., Pant, P., Dumka, U. C., Hegde, P., and Venkataramani, S.: Influences of the springtime northern Indian biomass burning over the central Himalayas, J. Geophys. Res., 116, D19302, https://doi.org/10.1029/2010JD015509, 2011.

Kummerow, C., Barnes, W., Kozu, T., Shiue, J., and Simpson, J.: The Tropical Rainfall Measuring Mission (TRMM) sensor package, J. Atmos. Ocean. Tech., 15, 809-816, https://doi.org/10.1175/15200426(1998)015<0809:TTRMMT>2.0.CO;2, 1998.

Kunze, M., Braesicke, P., Langematz, U., Stiller, G., Bekki, S., Brühl, C., Chipperfield, M., Dameris, M., Garcia, R., and Giorgetta, M.: Influences of the Indian Summer Monsoon on Water Vapor and Ozone Concentrations in the UTLS as Simulated by Chemistry-Climate Models, J. Climate, 23, 3525-3544, https://doi.org/10.1175/2010JCLI3280, 2010.

Lamarque, J.-F., Bond, T. C., Eyring, V., Granier, C., Heil, A., Klimont, Z., Lee, D., Liousse, C., Mieville, A., Owen, B., Schultz, M. G., Shindell, D., Smith, S. J., Stehfest, E., Van Aardenne, J., Cooper, O. R., Kainuma, M., Mahowald, N., McConnell, J. R., Naik, V., Riahi, K., and van Vuuren, D. P.: Historical (1850-2000) gridded anthropogenic and biomass burning emissions of reactive gases and aerosols: methodology and application, Atmos. Chem. Phys., 10, 7017-7039, https://doi.org/10.5194/acp-10-7017-2010, 2010.

Lau, K. M. and Kim, K. M.: Observational relationships between aerosol and Asian monsoon rainfall, and circulation, Geophys. Res. Lett., 33, L21810, https://doi.org/10.1029/2006GL027546, 2006.

Lelieveld, J., Crutzen, P. J., Ramanathan, V., Andreae, M. O., Brenninkmeijer, C. A. M., Campos, T., Cass, G. R., Dickerson, R. R., Fischer, H., de Gouw, J. A., Hansel, A., Jefferson, A., Kley, D., de Laat, A. T. J., Lal, S., Lawrence, M. G., Lobert, J. M., Mayol- Bracero, O. L., Mitra, A. P., Novakov, T., Oltmans, S. J., Prather, K. A., Reiner, T., Rodhe, H., Scheeren, H. A., Sikka, D., and Williams, J.: The Indian Ocean Experiment: Widespread Air Pollution from South and Southeast Asia, Science, 291, 10311036, https://doi.org/10.1126/science.1057103, 2001.

Li, C. and Yanai, M.: The onset and interannual variability of the Asian summer monsoon in relation to land-sea thermal contrast, J. Climate, 9, 358-375, https://doi.org/10.1175/15200442(1996)009<0358:TOAIVO>2.0.CO;2, 1996.

Li, J.-L. F., Walilser, D. E., Chen, W. T., Guan, B., Kubar, T., Stephens, G., Ma, H. Y., Deng, M., Donner, L., Seman, C., and Horowitz, L.: An observationally based evaluation of cloud ice water in CMIP3 and CMIP5 GCMs and contemporary reanalyses using contemporary satellite data, J. Geophys. Res., 117, D16105, https://doi.org/10.1029/2012JD017640, 2012.

Li, J.-L. F., Waliser, D. E., Stephens, G., Lee, S., L'Ecuyer, T., Kato, S., Loeb, N., and Ma, H. Y.: Characterizing and understanding radiation budget biases in CMIP3/CMIP5 GCMs, contemporary GCM, and reanalysis, J. Geophys. Res., 118, 8166-8184, https://doi.org/10.1002/jgrd.50378, 2013.

Li, Q., Jiang, J. H., Wu, D. L., Read, W. G., Livesey, N. J., Waters, J. W., Zhang, Y., Wang, B., Filipiak, M. J., Davis, C. P., Turquety, S., Wu, S., Park, R. J., Yantosca, R. M., and Jacob, D. J.: Convective outflow of South Asian pollution: A global CTM simulation compared with EOS MLS observations, Geophys. Res. Lett., 32, L14826, https://doi.org/10.1029/2005GL022762, 2005. 
Lin, C.-Y., Zhao, C., Liu, X., Lin, N.-H., and Chen, W.-N.: Modelling of long-range transport of southeast Asia biomass-burning aerosols to Taiwan and their radiative forcings over EAST ASIA, Tellus B, 66, 23733, https://doi.org/10.3402/tellusb.v66.23733, 2014.

Lin, N. H., Tsay, S.-C., Maring, H. B., Yen, M. C., Sheu, G. R., Wang, S. H., Chi, K. H., Chuang, M. T., Feng C., Yang, O., Fu, J. S., Reid, J. S., Lee, C.-T., Wang, L.-C., Wang, J.-L., Hsu, C. N., Sayer, A. M., Holben, B. N., Chu, Y.-C., Nguyen, X. A., Sopajaree, K., Chen, S.-J., Cheng, M.-T., Tsuang, B.-J., Tsai, C.J., Peng, C.-M., Schnell, R. C., Conway, T., Chang, C.-T., Lin, K.-S., Tsai, Y. I., Lee, W.-J., Chang, S.-C., Liu, J.-J., Chiang, W.-L., Huang, S.-J., Lin, T.-H., and Liu, G.-R.: An overview of regional experiments on biomass burning aerosols and related pollutants in Southeast Asia: From BASE-ASIA and the Dongsha Experiment to 7-SEAS, Atmos. Environ., 78, 1-19, https://doi.org/10.1016/j.atmosenv.2013.04.066, 2013.

Liu, H.-L., Wang, P. K., and Schlesinger, R. E.: A numerical study of cirrus clouds. Part II: Effects of Ambient Temperature, Stability, Radiation, Ice Microphysics, and Microdynamics on Cirrus Evolution, J. Atmos. Sci., 60, 1097-1119, https://doi.org/10.1175/15200469(2003)060<1097: ansocc >2.0.co;2, 2003.

Lohmann, U. and Ferrachat, S.: Impact of parametric uncertainties on the present-day climate and on the anthropogenic aerosol effect, Atmos. Chem. Phys., 10, 11373-11383, https://doi.org/10.5194/acp-10-11373-2010, 2010.

Lu, Z., Zhang, Q., and Streets, D. G.: Sulfur dioxide and primary carbonaceous aerosol emissions in China and India, 1996-2010, Atmos. Chem. Phys., 11, 9839-9864, https://doi.org/10.5194/acp-11-9839-2011, 2011.

Manoj, M. G., Devara, P. C. S., Safai, P. D., and Goswami, B. N.: Absorbing aerosols facilitate transition of Indian monsoon breaks to active spells, Clim. Dynam., 37, 2181-2198, https://doi.org/10.1007/s00382-010-0971-3, 2011.

Meehl, G. A.: Coupled land-ocean-atmosphere processes and South Asian monsoon variability, Science, 266, 263-267, https://doi.org/10.1126/science.266.5183.263, 1994.

Meehl, G. A., Arblaster, J. M., and Collins, W. D.: Effects of black carbon aerosols on the Indian monsoon, J. Climate, 21, 28692882, https://doi.org/10.1175/2007JCLI1777.1, 2008.

Menon, S., Hansen, J., Nazarenko, L., and Luo, Y.: Climate Effects of Black Carbon Aerosols in China and India, Science, 297, 2250-2253, https://doi.org/10.1126/science.1075159, 2002.

Mieville, A., Granier, C., Liousse, C., Guillaume, B., Mouillot, F., Lamarque, J. F., Gregoire, J. M., and Petron, G.: Emissions of gases and particles from biomass burning using satellite data and an historical reconstruction, Atmos. Environ., 44, 1469-1477, https://doi.org/10.1016/j.atmosenv.2010.01.011, 2010.

Myhre, G., Shindell, D., Bréon, F. M., Collins, W., Fuglestvedt, J., Huang, J., Koch, D., Lamarque, J.-F., Lee, D., Mendoza, B., Nakajima, T., Robock, A., Stephens, G., Takemura, T., and Zhang, H.: Anthropogenic and Natural Radiative Forcing, in: Climate Change 2013: The Physical Science Basis. Contribution of Working Group I to the Fifth Assessment Report of the Intergovernmental Panel on Climate Change, edited by: Stocker, T. F., Qin, D., Plattner, G.-K., Tignor, M., Allen, S. K., Boschung, J., Nauels, A., Xia, Y., Bex, V., and Midgley, P. M., Cambridge
University Press, Cambridge, United Kingdom and New York, NY, USA, 2013.

Neubauer, D., Lohmann, U., Hoose, C., and Frontoso, M. G.: Impact of the representation of marine stratocumulus clouds on the anthropogenic aerosol effect, Atmos. Chem. Phys., 14, 1199712022, https://doi.org/10.5194/acp-14-11997-2014, 2014.

Pan, X., Chin, M., Gautam, R., Bian, H., Kim, D., Colarco, P. R., Diehl, T. L., Takemura, T., Pozzoli, L., Tsigaridis, K., Bauer, S., and Bellouin, N.: A multi-model evaluation of aerosols over South Asia: common problems and possible causes, Atmos. Chem. Phys., 15, 5903-5928, https://doi.org/10.5194/acp15-5903-2015, 2015.

Park, M., Randel, W. J., Gettelman, A., Massie, S. T., and Jiang, J. H.: Transport above the Asian summer monsoon anticyclone inferred from Aura Microwave Limb Sounder tracers, J. Geophys. Res., 112, D16309, https://doi.org/10.1029/2006JD008294, 2007.

Park, M., Randel, W. J., Emmons, L. K., Bernath, P. F., Walker, K. A., and Boone, C. D.: Chemical isolation in the Asian monsoon anticyclone observed in Atmospheric Chemistry Experiment (ACE-FTS) data, Atmos. Chem. Phys., 8, 757-764, https://doi.org/10.5194/acp-8-757-2008, 2008.

Park, M., Randel, W. J., Emmons, L. K., and Livesey, N. J.: Transport pathways of carbon monoxide in the Asian summer monsoon diagnosed from Model of Ozone and Related Tracers (MOZART), J. Geophys. Res., 114, D08303, https://doi.org/10.1029/2008JD010621, 2009.

Penner, J. E., Chuang, C. C., and Grant, K.: Climate forcing by carbonaceous and sulfate aerosols, Clim. Dynam., 14, 839-851, https://doi.org/10.1007/s003820050259, 1998.

Ploeger, F., Fueglistaler, S., Grooß, J.-U., Günther, G., Konopka, P., Liu, Y. S., Müller, R., Ravegnani, F., Schiller, C., Ulanovski, A., and Riese, M.: Insight from ozone and water vapour on transport in the tropical tropopause layer (TTL), Atmos. Chem. Phys., 11, 407-419, https://doi.org/10.5194/acp-11-407-2011, 2011.

Ploeger, F., Konopka, P., Müller, R., Fueglistaler, S., Schmidt, T., Manners, J., Grooss, J.-U., Günther, G., de Forster, P. M., and Riese, M.: Horizontal transport affecting trace gas seasonality in the tropical tropopause layer TTL, J. Geophys. Res., 117, D09303, https://doi.org/10.1029/2011JD017267, 2012.

Ploeger, F., Günther, G., Konopka, P., Fueglistaler, S., Müller, R., Hoppe, C., Kunz, A., Spang, R., Grooß, J.-U., and Riese, M.: Horizontal water vapor transport in the lower stratosphere from subtropics to high latitudes during boreal summer, J. Geophys. Res.-Atmos., 118, 8111-8127, https://doi.org/10.1002/jgrd.50636, 2013.

Powell, K., Vaughan, M., Winker, D., Lee, K. M., Pitts, M., and Trepte, C.: CALIPSO Data Product Catalog, Release 3.6, Document No: PC-SCI-503, 2013.

Rahul, P. R. C., Bhawar, R. L., Ayantika, D. C., Panicker, A. S., Safai, P. D., Tharaprabhakaran, V., Padmakumari, B., and Raju, M. P.: Double blanket effect caused by two layers of black carbon aerosols escalates warming in the Brahmaputra River Valley, Sci. Rep., 4, 3670, https://doi.org/10.1038/srep03670, 2014.

Rajagopalan, B. and Molnar, P.: Signatures of Tibetan Plateau heating on Indian summer monsoon rainfall variability, J. Geophys. Res.-Atmos., 118, 1170-1178, https://doi.org/10.1002/jgrd.50124, 2013. 
Ramanathan, V. and Carmichael, G.: Global and regional climate changes due to black carbon, Nat. Geosci., 1, 221-227, https://doi.org/10.1038/ngeo156, 2008.

Ramanathan, V. and Crutzen, P. J.: New directions: Atmospheric brown "clouds", Atmos. Environ., 37, 4033-4035, https://doi.org/10.1016/S1352-2310(03)00536-3, 2003.

Ramanathan, V., Crutzen, P. J., Lelieveld, J., Mitra, A. P., Althausen, D., Anderson, J., Andreae, M. O., Cantrell, W., Cass, G. R., Chung, C. E., Clarke, A. D., Coakley, J. A., Collins, W. D., Conant, W. C., Dulac, F., Heintzenberg, J., Heymsfield, A. J., Holben, B., Howell, S., Hudson, J., Jayaraman, A., Kiehl, J. T., Krishnamurti, T. N., Lubin, D., McFarquhar, G., Novakov, T., Ogren, J. A., Podgorny, I. A., Prather, K., Priestley, K., Prospero, J. M., Quinn, P. K., Rajeev, K., Rasch, P., Rupert, S., Sadourny, R., Satheesh, S. K., Shaw, G. E., Sheridan, P., and Valero, F. P. J.: Indian Ocean Experiment: An integrated analysis of the climateforcing and effects of the great Indio-Asian haze, J. Geophys. Res., 106, 28371-28398, 2001a.

Ramanathan, V., Crutzen, P. J., Kiehl, J. T., and Rosenfeld, D.: Aerosols, Climate, and the Hydrological Cycle, Science, 294, 2119-2124, https://doi.org/10.1126/science.1064034, 2001b.

Ramaswamy, V. and Ramanathan, V.: Solar absorption of cirrus clouds and the maintenance of the tropical upper troposphere thermal structure. J. Atmos. Sci., 46, 2293-2310, https://doi.org/10.1175/15200469(1989)046<2293:SABCCA>2.0.CO;2, 1989.

Randall, D. A., Harshovardan, Dazlich, D. A., and Corsetti, T. G.: Interactions among radiation, convection, and largescale dynamics in a general circulation model, J. Atmos. Sci., 46, 1943-1970, https://doi.org/10.1175/15200469(1989)046<1943:IARCAL>2.0.CO;2, 1989.

Randel, W. J. and Park, M.: Deep convective influence on the Asian summer monsoon anticyclone and associated tracer variability observed with Atmospheric Infrared Sounder (AIRS), J. Geophys. Res., 111, D12314, https://doi.org/10.1029/2005JD006490, 2006.

Randel, W. J., Park, M., Emmons, L., Kinnison, D., Bernath, P., Walker, K. A., Boone, C., and Pumphrey H.: Asian monsoon transport of pollution to the stratosphere, Science, 328, 611-613, https://doi.org/10.1126/science.1182274, 2010.

Rosenfield, D.: Suppression of rain and snow by urban and industrial air pollution, Science, 287, 1793-1796, https://doi.org/10.1126/science.287.5459.1793, 2000.

Satheesh, S. K. and Ramanathan, V.: Large differences in tropical aerosol forcing at the top of the atmosphere and Earth's surface, Nature, 405, 60-63, https://doi.org/10.1038/35011039, 2000.

Schultz, M. G., Heil, A., Hoelzemann, J. J., Spessa, A., Thonicke, K., Goldammer, J., Held, A. C., Pereira, J. M., and van het Bolscher, M.: Global wildland fire emissions from 1960 to 2000, Global Biogeochem. Cy., 22, GB2002, https://doi.org/10.1029/2007GB003031, 2008.

Solomon, S., Qin, D., Manning, M., Chen, Z., Marquis, M., Averyt, K. B., Tignor, M., and Miller, H. L.: Contribution of Working Group I to the Fourth Assessment Report of the Intergovernmental Panel on Climate Change,Cambridge University Press, Cambridge, UK and New York, NY, USA, 2007.

Sreekanth, V., Niranjan, K., and Madhavan, B. L.: Radiative forcing of black carbon over eastern India, Geophys. Res. Lett., 34, L17818, https://doi.org/10.1029/2007GL030377, 2007.
Stephens, G. L., Vane, D. G., Taneeli, S., Im, E., Durden, S., Rockey, M., Reinke, D., Partain, P., Mace, G. G., Austin, R., Ecuyet, T. L., Haynes, J., Lebsock, M., Suzuki, K., Waliser, D., Wu, D., Kay, J., Gettelman, A., Wang, Z., and Marchand, R.: CloudSat mission: Performance and early science after the first year of operation, J. Geophys. Res., 113, D00A18, https://doi.org/10.1029/2008JD009982, 2008.

Stevens, B., Giorgetta, M., Esch, M., Mauritsen, T., Crueger, T., Rast, S., Salzmann, M., Schmidt, H., Bader, J., Block, K., Brokopf, R., Fast, I., Kinne, S., Kornblueh, L., Lohmann, U., Pincus, R., Reichler, T., and Roeckne, E.: Atmospheric component of the MPI-M Earth System Model: ECHAM6, Journal of Advances in Modeling Earth Systems, 5, 1-27, https://doi.org/10.1002/jame.20015, 2013.

Stier, P., Feichter, J., Kinne, S., Kloster, S., Vignati, E., Wilson, J., Ganzeveld, L., Tegen, I., Werner, M., Balkanski, Y., Schulz, M., Boucher, O., Minikin, A., and Petzold, A.: The aerosol-climate model ECHAM5-HAM, Atmos. Chem. Phys., 5, 1125-1156, https://doi.org/10.5194/acp-5-1125-2005, 2005.

Streets, D. G., Yan, F., Chin, M., Diehl, T., Mahowald, N., Schultz, M., Wild, M., Wu, Y., and Yu, C.: Anthropogenic and natural contributions to regional trends in aerosol optical depth, 1980-2006, J. Geophys. Res., 114, D00D18, https://doi.org/10.1029/2008jd011624, 2009.

Takahashi, H. G.: Seasonal and diurnal variations in rainfall characteristics over the tropical Asian monsoon region using TRMMPR data, SOLA, 12, 22-27, https://doi.org/10.2151/sola.12A005, 2016.

Tegen, I., Harrison, S. P., Kohfeld, K., Prentice, I. C., Coe, M., and Heimann, M.: Impact of vegetation and preferential source areas on global dust aerosol: Results from a model study, J. Geophys. Res.-Atmos., 107, 4576, https://doi.org/10.1029/2001JD000963, 2002.

Thomason, L. W. and Vernier, J.-P.: Improved SAGE II cloud/aerosol categorization and observations of the Asian tropopause aerosol layer: 1989-2005, Atmos. Chem. Phys., 13, 4605-4616, https://doi.org/10.5194/acp-13-4605-2013, 2013.

Tobo, Y., Iwasaka, Y., Yu Shi, G., Kim, Y. S., Ohashi, T., Tamura, K., and Zhang, D.: Balloon-borne observations of high aerosol concentrations near the summertime tropopause over the Tibetan Plateau, Atmos. Res., 84, 233-241, https://doi.org/10.1016/j.atmosres.2006.08.003, 2007.

Tripathi, S. N., Srivastava, A. K., Dey, S. S., Satheesh, S. K., and Krishnamoorthy, K.: The vertical profile of atmospheric heating rate of black carbonaerosols at Kanpur in northern India, Atmos. Environ., 41, 6909-6915, https://doi.org/10.1016/j.atmosenv.2007.06.032, 2007.

van der Werf, G. R., Randerson, J. T., Giglio, L., Collatz, G. J., Kasibhatla, P. S., and Arellano Jr., A. F.: Interannual variability in global biomass burning emissions from 1997 to 2004, Atmos. Chem. Phys., 6, 3423-3441, https://doi.org/10.5194/acp-6-34232006, 2006.

Vernier, J. P., Thomason, L. W., and Kar, J.: CALIPSO detection of an Asian tropopause aerosol layer, Geophys. Res. Lett., 38, L07804, https://doi.org/10.1029/2010GL046614, 2011.

Vernier, J. P., Fairlie, T. D., Natarajan, M., Wienhold, F. G., Bian, J., Martinsson, B. G., Crumeyrolle, S., Thomason, L. W., and Bedka, K. M.: Increase in upper tropospheric and lower stratospheric aerosol levels and its potential connection 
with Asian pollution, J. Geophys. Res.-Atmos., 120, 1608-1619, https://doi.org/10.1002/2014JD022372, 2015.

Vignati, E., Wilson, J., and Stier, P.: An efficient sizeresolved aerosol microphysics module for large-scale aerosol transport models, J. Geophys. Res., 109, D22202, https://doi.org/10.1029/2003JD004485, 2004.

Vinoj, V., Rasch, P. J., Wang, H., Yoon, J.-H., Ma, P.-L., Landu, K., and Singh, B.: Short-term modulation of Indian summer monsoon rainfall by West Asian dust, Nat. Geosci., 7, 308-313, https://doi.org/10.1038/ngeo2107, 2014.

Vogel, B., Pan, L. L., Konopka, P., Günther, G., Müller, R., Hall, W., Campos, T., Pollack, T., Weinheimer, A., Wei, J., Atlas, E. L., and Bowman, K. P.: Transport pathways and signatures of mixing in the extratropical tropopause region derivedfrom Lagrangian model simulations, J. Geophys. Res., 116, D05306, https://doi.org/10.1029/2010JD014876, 2011.

Vogel, B., Günther, G., Müller, R., Grooß, J.-U., and Riese, M.: Impact of different Asian source regions on the composition of the Asian monsoon anticyclone and of the extratropical lowermost stratosphere, Atmos. Chem. Phys., 15, 13699-13716, https://doi.org/10.5194/acp-15-13699-2015, 2015.

Wang, B. and LinHo: Rainy Season of the Asian-Pacific Summer Monsoon, J. Climate, $\quad 15, \quad 386-398, \quad$ https://doi.org/10.1175/15200442(2002)015<0386:RSOTAP>2.0.CO;2, 2002.

Wang, C.: A modeling study on the climate impacts of black carbon aerosols, J. Geophys. Res., 109, D03106, https://doi.org/10.1029/2003JD004084, 2004.

Wang, C.: Impact of direct radiative forcing of black carbon aerosols on tropical convective precipitation, Geophys. Res. Lett., 34, L05709, https://doi.org/10.1029/2006GL028416, 2007.

Wang, C., Kim, D., Ekman, A. M. L., Barth, M. C., and Rasch, P. J.: Impact of anthropogenic aerosols on Indian summer monsoon, Geophys. Res. Lett., 36, L21704, https://doi.org/10.1029/2009GL040114, 2009.

Winiger, P., Andersson, A., Eckhardt, S., Stohl, A., and Gustafsson, O.: The sources of atmospheric black carbon at a European gateway to the Arctic, Nat.Commun., 7, 12776, https://doi.org/10.1038/ncomms12776, 2016.
Winker, D., Pelon, J., Coakley, J., Ackerman, S., Charlson, R., Colarco, P., Flamant, P., Fu, Q., Hoff, R., Kittaka, C., Kubar, T. L., Le Treut, H., McCormick, M. P., Mégie, G., Poole, L., Powell, K., Trepte, C., Vaughan, M. A., and Wielicki, B. A.: THE CALIPSO MISSION A Global 3D View of Aerosols and Clouds, B. Am. Meteorol. Soc., 91, 1211-1229, https://doi.org/10.1175/2010bams3009.1,2010.

$\mathrm{Wu}, \mathrm{G}$. and Zhang, Y.: Tibetan Plateau forcing and timing of the monsoon onset over South Asia and South China Sea, Mon. Weather Rev., 126, 913-927, https://doi.org/10.1175/15200493(1998)126<0913:tpfatt>2.0.co;2, 1998.

Xie, P., Yatagai, A., Chen, M., Hayasaka, T., Fukushima, Y., Liu, C., and Yang, S.: A Gauge-Based Analysis of Daily Precipitation over East Asia, J. Hydrometeorol., 8, 607-626, https://doi.org/10.1175/JHM583.1, 2007.

Xiong, X., Houweling, S., Wei, J., Maddy, E., Sun, F., and Barnet, C.: Methane plume over south Asia during the monsoon season: satellite observation and model simulation, Atmos. Chem. Phys., 9, 783-794, https://doi.org/10.5194/acp-9-783-2009, 2009.

Yanai, M., Li, C., and Song, Z.: Seasonal heating of the Tibetan Plateau and its effects on the evolution of the Asian summer monsoon, J. Meteorol. Soc. Jpn., 70, 189-221, 1992.

Yu, P., Toon, O. B., Neely, R. R., Martinsson, B. G., and Brenninkmeijer, C. A. M.: Composition and physical properties of the Asian Tropopause Aerosol Layer and the North American Tropospheric Aerosol Layer, Geophys. Res. Lett., 42, 2540-2546, https://doi.org/10.1002/2015GL063181, 2015.

Zhang, K., O’Donnell, D., Kazil, J., Stier, P., Kinne, S., Lohmann, U., Ferrachat, S., Croft, B., Quaas, J., Wan, H., Rast, S., and Feichter, J.: The global aerosol-climate model ECHAM-HAM, version 2: sensitivity to improvements in process representations, Atmos. Chem. Phys., 12, 8911-8949, https://doi.org/10.5194/acp-12-8911-2012, 2012.

Zhang, L., Henze, D. K., Grell, G. A., Carmichael, G. R., Bousserez, N., Zhang, Q., Torres, O., Ahn, C., Lu, Z., Cao, J., and Mao, Y.: Constraining black carbon aerosol over Asia using OMI aerosol absorption optical depth and the adjoint of GEOS-Chem, Atmos. Chem. Phys., 15, 10281-10308, https://doi.org/10.5194/acp-1510281-2015, 2015. 